\title{
Real Assets, Liquidation Value and Choice of Financing
}

\author{
by
}

Crocker Liu ${ }^{1}$, Peng $\mathrm{Liu}^{2}$, and Zhipeng Zhang ${ }^{3}$

\footnotetext{
${ }^{1}$ Cornell University, Center for Real Estate Finance and School of Hotel Administration, Ithaca, NY 14853, phone: 607-255-3739, e-mail: chl62@cornell.edu.

${ }^{2}$ Cornell University, Center for Real Estate Finance and School of Hotel Administration, 465 Statler Hall, Ithaca, NY 14853, phone: 607-254-2960, fax: 607-255-1277, e-mail: pl333@cornell.edu.

${ }^{3}$ Boston College, Carroll School of Management, Chestnut Hill, MA 02467, phone: 617552-4863, e-mail: zhangzc@bc.edu.
} 


\title{
Real Assets, Liquidation Value and Choice of Financing
}

\begin{abstract}
We use real estate firms to examine how asset liquidation values influence a firm's financing choices, since the productivity and quality of each asset is observable and potential measures of an asset's liquidation value are easier to ascertain ex-ante. We show that compared to firms that issue equity, firms that issue debt have higher asset quality. The effect of their expected asset liquidation value is significant, even after we control for other factors that influence financing decisions. For firms whose assets' quality is not easily observable, we find that firms' financing choices depend heavily on conditions in the overall real asset market. (JEL: G3, R0, G33)
\end{abstract}


The illiquidity of corporate assets poses a significant private cost to firms that choose to finance with debt. When a firm is in financial distress and has to liquidate its assets, potential industry buyers, e.g., peers within the same industry, are also likely to be financially constrained or experiencing similar business difficulties, thus they cannot pay full value for the assets. Shleifer and Vishny (1992), who explore the effect of liquidation values on corporate debt capacity, predict that firms with relatively more illiquid assets will prefer equity financing to debt, ex ante. In this paper, we test the Shleifer and Vishny hypothesis that asset liquidation values influence firms financing choices. We do so by examining the incremental financing decisions of real estate firms, the real estate investment trusts (REITs).

We choose to focus on real estate firms rather than ordinary corporations to analyze the role that asset liquidation values play in determining a firm's financial contracts. We do so for several reasons. First, prior studies have used commercial real estate to test the Shleifer and Vishny (1992) hypothesis. As Benmelech, Garmaise, and Moskowitz (2005) note, the real estate market is a natural candidate for testing financial contracting, given its high levels of debt coupled with potential measures of an asset's liquidation value, which is usually difficult to ascertain ex ante. In addition, relative to most industries, REITs are more homogeneous and offer greater transparency (see, e.g., Capozza and Seguin, 1999) with respect to their operations and assets. In contrast to other types of corporations, the comparative advantage of using REITs is that the productivity, asset quality, and other asset characteristics, all essential features in determining an asset's liquidation value and optimal financing of a project are observable for each asset (property). Further, real estate constitutes a nontrivial portion of the assets held on the balance sheet of corporations. According to Chaney, Sraer, and Thesmar (2010), 58 percent of U.S. public firms in 1993 reported at least some real estate ownership, with real estate accounting for 19 percent of these firms' total market value. Thus, our analysis may provide new insights on the redeployability of assets and liquidation value for other industries with tangible fixed assets (property, plant, and 
equipment, PP\&E). Furthermore, as Campello and Giambona (2010) point out, among the various categories of tangible assets, the real estate component of PP\&E (land and buildings) has the most explanatory power over leverage.

Using prior research ${ }^{1}$ as our starting point, we examine the variation in debt capacity relative to the determinants of liquidation value by focusing on asset quality. The potential quality of a firm's asset includes an analysis of both tenant quality and the sustainability of the cash flows associated with the asset over the business cycle rather than the potential buyers of such assets. The reason goes to the issue of value in best use, since the asset (in this case, real estate) consists of a bundle of existing and future lease contracts. Consequently, the tenant quality and the economic base of the local real estate market affect whether asset sales are at prices below the value in best use. Since real estate is fixed in its location, the health of the local economy influences the cash flow of the tenant and hence its decision to remain in its contract. Therefore, potential buyers face a decision on assessing the value in best use, given the quality of the asset in question relative to the desirability of the local region. This emphasis is the distinguishing feature of our study. We theoretically prove and empirically test the notion that asset quality, which we measure by tenant financial stability, together with the industry concentration structure of the local real estate market, determines the liquidation value of real estate and a firm's financing choices. Our intrinsic measures of asset liquidation value include the industry concentration of local markets, which captures the long-term zoning flexibility notion of Benmelech, Garmaise, and Moskowitz (2005) and a measure of tenant financial stability, which reflects the short-run or intermediate-term asset quality.

Our model also predicts a set of market indicators that should influence asset liquidation

\footnotetext{
${ }^{1}$ Our work builds on earlier research that empirically tests the effect of liquidation value on a firm's capital structure choices. For example, Benmelech and Bergman (2008), who study the U.S. airline industry and Benmelech (2009), who examines the 19th century American railroad industry, find that firms with more saleable real assets and redeployable collateral tend to have lower costs of external financing and longer maturities associated with debt financing.
} 
value. In equilibrium, capital market participants should observe the intrinsic information of asset qualities and react to them accordingly. We propose two such market indicators: the realized loss severity from real estate loans (the historical measure) and the capitalization rate (a forward-looking measure). We note that the capitalization rate (cap rate), which is analogous to the inverse of the EBITDA multiple (earnings before interest, taxes, depreciation and amortization divided by enterprise value), is one of the most important market indicators in real estate (see Plazzi, Torous, and Valkanov, 2010).

Another distinguishing feature of our study is that we use the choice of a firm's security issuance as the dependent variable rather than using leverage ratios. By focusing on a firm's incremental financing decisions, our approach deals with the persistence problem of using leverage ratios (see, e.g., Lemmon, Roberts, and Zender, 2006), which may yield misleading coefficients (Strebulaev, 2007).

The paper is organized as follows. In Section 1 we provide a reduced-form model of firm liquidation value. The model helps us disentangle the intrinsic asset characteristics from the market proxy for liquidation value, which guides the empirical tests. In Section 2, we discuss four measures of asset liquidation value. In Section 3 we describe our sample and in Section 4 we test the Shleifer and Vishny (1992) hypothesis. Section 5 concludes.

\section{A Model of Firm Liquidation Value}

A real estate firm (REIT) operates a portfolio of commercial real estate assets, which generates a constant cash flow ${ }^{2}$ of $I$ per unit of time until default. A default event occurs according to a Poisson process with an exogenous hazard intensity of $\lambda$.

Federal regulations require that REITs must hold at least $75 \%$ of its assets in real estate. Therefore, we assume that the firm's value equals the total value of the assets it holds. We further assume that due to private information, geographical expertise, and reputation

\footnotetext{
${ }^{2}$ In reality, net operating income, which is rental income net of operating expenses, may not be a constant. We provide an alternative cash flow specification in the Appendix. The major result remains the same.
} 
developed in operating the portfolio of real assets, the current firm is the first-best owner, in the sense that the real assets under current REIT management generate the highest cash flows until the event of default.

In fact, the informal arguments that link the firm's liquidation value to the best use of assets are often maintained as the following quotation from Shleifer and Vishny (1992) indicate:

"Because of credit constraints and government regulation of industry buyers, assets would have to be sold to industry outsiders who don't know how to manage them well, face agency costs of hiring specialists to run these assets properly. When industry buyers cannot buy the assets and industry outsiders face significant costs of acquiring and managing the assets, assets in liquidation fetch prices below value in best use, which is the value when managed by specialists."

Formally, if it defaults, the REIT liquidates its portfolio of real assets as a whole to homogeneous second-best owners in the competitive secondary market. Over time, the new owners gradually obtain private information, develop expertise, and rebuild the reputation by managing the assets. Hence, over time, the cash flow reverts to the pre-default level. We assume that the cash flow generated under the management of the second-best owner is $\left(1-\beta e^{-\kappa t}\right) I$, where $\beta \in(0,1)$ captures the instant discount of the cash flow at liquidation; $\kappa$ measures the speed of cash flow recovery to its pre-default level, and $t$ is the length of time after default.

All market participants are risk-neutral and discount future cash flows by the constant risk-free rate, $r$. The market value of the firm is the sum of the present value of its cash flow until default and the present value of the liquidation value upon default:

$$
V_{0}=E_{0}\left[\int_{0}^{\tau_{\lambda}} e^{-r s} I d s+e^{-r \tau_{\lambda}} V_{1}\right]
$$


where we assume the current time is zero and denote $\tau_{\lambda}$ as the time of default. $E_{0}(\cdot)$ is the expectation taken at time $0 . V_{1}$ is the market value of the liquidating real assets at $\tau_{\lambda} . V_{1}$ is the sum of the present value of the cash flows under a new REIT until the next default and the present value of the liquidation value upon the next default:

$$
V_{1}=E_{0}\left[\int_{0}^{\tau_{\lambda}^{\prime}} e^{-r t}\left(1-\beta e^{-\kappa t}\right) I d t+e^{-r \tau_{\lambda}^{\prime}} V_{1}\right]
$$

where $\tau_{\lambda}^{\prime}$ denotes the time between the first and the second defaults. The terminal value is also $V_{1}$ because upon the second default, the homogeneous and competitive second-best owners are facing exactly the same situation as the REIT faces at the first default. Solving Equation (2), we get the firm's liquidation value as:

$$
V_{1}=\frac{I}{r}\left(1-\beta \frac{r+\lambda}{r+\lambda+\kappa}\right) .
$$

To make the firm's liquidation value scalable, we normalize the terminal liquidation value $V_{1}$ by its current market value $V_{0}$. From Equation (1), we can write the current market value as

$$
V_{0}=\frac{1}{r+\lambda}\left(I+\lambda V_{1}\right)
$$

Therefore the normalized liquidation value is

$$
L \equiv \frac{V_{1}}{V_{0}}=\frac{(r+\lambda) V_{1}}{\left(I+\lambda V_{1}\right)}
$$

When we examine the determinants that affect this normalized liquidation value, we find that the smaller the normalized liquidation value, $L$, the higher are the liquidation costs. Hence, according to Shleifer and Vishny (1992), the less likely the real estate firm is to finance with debt than equity ex ante. 


\section{The Determinants of Firm's Liquidation Value and Predictions of Financing Choice}

To test Shleifer and Vishny's (1992) hypothesis, we believe it is essential to measure a firm's liquidation value correctly. Our model presented in the previous section not only gives a theoretical foundation for the determinants of REIT liquidation value, but also provides a framework to analyze the relation between the firm's liquidation value and various market proxies. The model implies that asset quality and fire-sale discount can serve as the intrinsic measures of the firm's liquidation value. Furthermore, if there is an information feedback loop in the capital market, then the prior liquidations from similar assets and some market indicators of cash flow valuation will also predict the firm's liquidation value.

\subsection{Intrinsic Measures of Firm's Liquidation Value}

\subsubsection{Tenant Quality}

A higher quality of real assets implies more stable long-term cash flows. In the framework of our model, the new owner will be able to recover more quickly to the optimal level $(I)$ of cash flows (larger $\kappa)$. Asset quality, which is intrinsic to firm liquidation value, determines the speed of cash flow recovery $\kappa$. It follows from Equations (3) and (5) that

$$
\frac{\partial L}{\partial \kappa}=\frac{\beta I^{2}(r+\lambda)^{2}}{r\left(I+\lambda V_{1}\right)^{2}(r+\lambda+\kappa)^{2}}>0 .
$$

Therefore, the Equation (6) predicts that asset quality has a positive effect on the normalized liquidation value.

There are several ways to measure asset quality. Tax regulation requires that at least 95\% of REIT gross income must come from rental income or other passive investment such as Treasuries. Property value is defined as capitalized future rents, which are contracted in the 
properties' leases. Therefore, one way to measure cash flow stability is by its lease maturities. For example, a firm's real assets with long-term leases should have higher quality, because future cash flows are more stable for the asset owner over a long time period. However, in reality, the lease term tells only one side of the story.

Giambona, Harding, and Sirmans (2008) adapt the lease maturity structure as a measure of firm liquidation value. Using a sample of equity REITs, they find that shorter leases are likely to have higher liquidation values because the option value of re-leasing and modifying the property at more favorable conditions to a favorable tenants. However, the lease maturity is result of bargaining between lessor and lessee and reflects a balance between the cash flow stability and option value. Therefore, the lease expiration structure suffers from an endogeneity problem as a proxy for liquidation value.

Since the lease maturity is endogenously determined, it is not an ideal proxy for asset liquidation value. We argue that tenant quality is the main driver of asset liquidation value. Our reasoning is that there are also costs associated with long-term leases. When the longterm rent is higher than the market rent, the owner may experience lease defaults. When the long-term rent is lower than the market rent, the owner does not have the option to adjust the rent accordingly. Therefore, short-term leases give the property owner more control over property improvement, restructuring, and refinancing flexibility. Furthermore, the lease term and base lease are often bundled with lease escalation, percentage rent, and lease options (lease renewal, cancellation option, expansion option, etc.). Without other contract terms such as escalation and the options mentioned above, the lease maturity itself cannot capture the whole value of lease contract. The argument in Giambona, et al. 2008 holds only in an up market, but not necessarily in a down market because of the difficulty of re-leasing the space.

Most asset managers believe that the property is only as strong as the tenant (Smith, 2009). The tenant quality was highlighted during the 2007-2009 financial crisis. In the case 
of lease contracts, often referred to as the engines of property values, lease counterparty risk arises when a tenant with low creditworthiness may not be able to make rental payments. Therefore, the quality of lease contracts depends on the credit quality of the tenants. A tenant with better financial stability implies less counterparty risk, which means higher asset quality. We measure asset quality with the revenue-weighted Altman Z-score, which we construct using the historical performance of assets, liabilities, and earnings to predict a firm's probability of default.

To construct such a measure, we focus on the top tenants that provide at least 60 percent of the landlord firm's revenue and match all publicly traded tenants to Compustat. We calculate an average tenant Altman Z-score weighted by the percentage contribution of revenue of each tenant for every REIT firm in our sample.

Thus, our first hypothesis is as follows:

Hypothesis I: A REIT with higher average tenant Z-scores has higher asset quality and higher liquidation value. Therefore, a REIT with higher average tenant Z-scores tends to finance with debt.

\subsubsection{Industry Concentration of Local Markets}

One key problem with illiquid assets like real estate is that a hasty liquidation may cause significant private costs to the owner. When a financially constrained real estate firm wants to sell a property in a highly concentrated real estate market, it is likely that potential buyers are in similar financial distress. Consistent with this argument, real estate appraisers typically assume that a rapid sale of real estate leads to a liquidation discount (or fire-sale discount), since redeployment of the firm's assets is difficult. Shleifer and Vishny (1992) find that the liquidation discount is about 15 to 25 percent relative to an orderly sale. Kaplan (1989) cites Merrill Lynch estimates that the distressed sale of the Campeau retail empire would bring about 68 percent of what an orderly sale would bring. 
In our model, we capture such a liquidation discount by $\beta$, which represents an immediate drop in the generated cash flows at the time of liquidation. Based on Equations (3) and (5), we get

$$
\frac{\partial L}{\partial \beta}=-\frac{I^{2}(r+\lambda)^{2}}{r\left(I+\lambda V_{1}\right)^{2}(r+\lambda+\kappa)}<0 .
$$

Therefore, our model predicts a negative effect of the liquidation discount on the normalized liquidation value.

In our analysis, we measure the liquidation discount using the average industry concentration ratio of a REIT's top markets. Each local market is defined as a Metropolitan Statistical Area (MSA). The United States Office of Management and Budget (OMB) defines an MSA as one or more adjacent counties or county equivalents that have at least one urban core area of at least 50,000 population, plus adjacent territory that has a high degree of social and economic integration with the core as measured by commuting ties. The OMB has defined 366 MSAs in the U.S. For example, the New York metropolitan area (the New York-Northern New Jersey-Long Island MSA), which is the largest MSA in the U.S., includes ten counties in New York State, twelve counties in Northern and Central New Jersey, and one county in northeastern Pennsylvania. The idea is that REITs that invest in areas with a high industry concentration (less diversified mix of industries in a given locale) may have to offer a deeper discount to sell their assets, because the potential buyers may be suffering the same financial difficulty. For example, the redeployability of real estate assets in Detroit is much lower than in other areas, as most businesses in Detroit are associated with the auto industry.

Using commercial property zoning flexibility as a proxy for liquidation values, Benmelech, Garmaise, and Moskowitz (2005) find that higher liquidation values are associated with longer term loans, a smaller number of creditors, higher loan-to-value ratios, and lower interest rates. Although the flexibility in zoning designation that governs permitted uses of 
a property, is associated with the potential level of property redeployability, such effects might tend to influence the liquidation value in the long run. In fact, the flexibility option alluded to in Benmelech et al. (2005) is typically out of the money except when the age of the building is such that the building is in need of rehabilitation or can be torn down. Due to the long-term durability of real estate asset, when facing financing choices firms may be more interested in the determinants of liquidation value at short or intermediate horizons. In the short or intermediate term, there is a greater emphasis around asset quality such as the quality of tenants in a space. In a long-run market equilibrium, the zoning restriction and the local economic base should be integrated in a region that provides a unique industry structure. Therefore the industry concentration structure captures the long-run attractiveness of a market.

To construct such a proxy we first obtain the top ten markets for each REIT. Following Hirschman (1964), for each MSA we calculate a Herfindahl-Hirschman Index $(H H I), H H I=$ $\frac{\sum_{i=1}^{N} E_{i}^{2}}{\left(\sum E_{i}\right)^{2}}$, where $E_{i}$ is the number of employees in each industry category of a particular MSA. A higher HHI means a higher industry concentration. Doing so makes it possible for us to measure the extent of local real estate market diversification and industry concentration. If the labor force is wholly concentrated in a single industry, then the index is one. With the revenue-weighted average of the local market HHI as a proxy for fire-sale discount, we have our second hypothesis.

Hypothesis II: A lower industry concentration for a REIT's property markets is associated with higher asset liquidation values. Therefore, firms with lower average industry concentration ratios are more likely to finance with debt.

\subsection{Market Indicators of Firm's Liquidation Value}

We also test our hypotheses by using two market measures, the realized loss severity rate on securitized commercial mortgages and the firm-level cap rate. If the market is more or 
less efficient, some of the information about asset quality and attractiveness of real estate markets should be priced in realized liquidations and the cash flow valuation matrix.

\subsubsection{Loss Severity Rate}

We can also infer the asset liquidation value from realized foreclosures. Assuming that the historical liquidations indicate future performance, we use the realized loss severity rate $^{3}$ of publicly traded commercial mortgage backed security (CMBS) as a proxy of REITs' asset liquidation value.

We note that there may be some difference in liquidation values between properties collateralized in portfolio loans compared to those securitized in CMBS deals. However, the loss severity rates extracted in CMBS deals still provide a useful market measure for liquidation value across property types and over time. Thus, as a measure of loss severity, we exploit the average loss severity by property type from foreclosed real assets in securitized CMBS deals, provided by the U.S. structured products research of LehmanLive ${ }^{4}$. We build a realized CMBS loss severity indicator for each REIT according to its real asset exposure to test our third hypothesis.

Hypothesis III: A lower realized CMBS loss severity rate of a REIT indicates higher asset liquidation value. Therefore, firms with lower realized CMBS loss severity are more likely to finance with debt ex-ante.

\subsubsection{Cap Rate}

Our second market measure for asset liquidation value focuses on cash flow valuation and market transactions. If the market is informative, then the value of a firm's cash flow should

\footnotetext{
${ }^{3}$ The loss severity rate of a defaulted CMBS is defined as the present value of its lifetime losses (both interest and principal losses) as a percentage of principal balance, measured at either the origination date or the default date.

${ }^{4}$ LehmanLive becomes Barclays Capital Live after the Lehman Brothers was liquidated and acquired by Barclay Capital in 2009. We also use a similar index from Standard and Poor's CMBS Quarterly Insights. The results are essentially the same. We thank John Harding for providing Standard and Poor's CMBS quarterly data of loan defaults and losses.
} 
be reflected in the transaction price of a property. The cap rate is one of the most important factors determining the value of commercial real estate. (See Plazzi, Torous, and Valkanov, 2010).

We derive the relation between the cap rate and normalized liquidation value from the model framework presented in Section 1 . We define the cap rate $C$ as the net operating cash flow, $I$, divided by the market value of an asset, $V_{0}$ :

$$
C=\frac{I}{V_{0}}
$$

Solving for $L$, we obtain ${ }^{5}$

$$
\begin{gathered}
L=1+\frac{1}{\lambda}(r-C) . \\
\frac{\partial L}{\partial C}=-\frac{1}{\lambda}<0
\end{gathered}
$$

Therefore, our model predicts that a higher cap rate is associated with a lower normalized liquidation value. In contrast to the historical market proxy that uses the realized CMBS loss severity rate, the cap rate measures forward-looking capital market pricing. If investors are rational, with fixed next year net income, the price $\left(V_{0}\right)$ they are paying should reflect the intrinsic value of asset quality and local market information.

We use a panel data of cap rates across time and property types from RealtyRates.com. ${ }^{6}$ We compute an average cap rate based on property weights in various locations and property types. Hence, our final hypothesis is

Hypothesis IV: A lower capitalization rate indicates a higher asset liquidation value for the same set of cash flows. Therefore, firms with lower average capitalization rate measures are more likely to finance with debt.

\footnotetext{
${ }^{5}$ Divide both sides of (4) by $V_{0}$, we get $1=\frac{C+\lambda L}{r+\lambda}$, from which the normalized liquidation value is derived.

${ }^{6}$ Regression using cap rates from Real Capital Analytics or PWC Korpacz yields similar results.
} 


\section{Sample Data and Descriptive Analysis}

The variable of interest is the choice of incremental financing, i.e., debt or equity. The data on REITs' incremental financing decisions are from SNL Real Estate, which covers all equity REITs' public security offerings from January 2000 through December 2009. SNL Real Estate provides detailed information on REIT investments, firm financial characteristics, as well as information on geographical distribution of properties and tenant exposures; most of this information is not available on Compustat.

There are 2,150 new issues, including 921 bond issues and 1,229 equity issues from 183 REITs during the 2000-2009 period. We derive accounting information, such as total book assets, total debt, and returns on average assets, from Compustat, complemented when necessary by SNL Real Estate. Among the four ingredients of our liquidation value measures, the key factor is tenant quality. However, since some properties (e.g., hotels and apartments) do not have corporate tenants whose stock is publicly traded, we use the following three sample selection criteria:

Criteria 1: We remove observations if any one of the four liquidation measures is missing. This criterion results in 863 observations.

Criteria 2: From the sample screened from criterion 1, we add properties that are run by an operating company, ${ }^{7}$ or are mixed use. We believe that for hotels, apartments, and other property types with transient tenants, a property managed by a more efficient operator should have higher asset quality. Therefore we use an operator's quality to represent tenant quality. Criterion 2 generates 1,043 observations.

Criteria 3: From the sample generated using criterion 2, we add observations that have one of two market measures for liquidation value, either the cap rate or the loss severity. The sample that contains the cap rate comprises 1,448 observations. The sample that contains

\footnotetext{
${ }^{7}$ For example some hotel properties of Hospitality Properties Trust (HPT) are run by Hyatt Hotel Corp., or Intercontinental Hotels Group.
} 
the loss severity has 1,300 observations.

We use the sample generated from criterion 2 of 1,043 observations for our baseline regression. We use the samples produced from criteria 1 and 3 for robustness checks. The baseline regression sample contains 1,043 new offerings, which consist of 484 bond issues and 559 equity issues from 102 REITs. On average, there is one issue per firm per year.

[Put Table1 here]

Table 1 reports the descriptive statistics of security issuances by equity REITs between January 2000 and December 2009. Panel A reports the number of issuances and the number of firms that issue securities by REIT property type. SNL Real Estate defines eight property types: retail (including shopping centers, regional malls, and other retail outlets), office, industrial, apartment, lodging, health care, diversified, and other special property types. Since most REITs invest in one type of real estate, the industry often classifies REITs by the property type on which they focus. Panel B reports the number of issuances and the number of firms that issue securities by issuing year. Total issuance of public offerings is clustered in offices and shopping centers. There is also an apparent time variation in the average number of security issues per firm. The average peaks in 2004 with 179 total issues.

\section{[Put Table 2 here]}

Table 2 presents the distribution of new security issues by REIT property focus (panel A) and by issuing year (panel B). REITs that choose to issue bonds are larger in size than REITs that issue equity. This phenomenon is consistent with the general notion that large firms are more likely to have access to the bond markets than small firms. The apartment sector, which has special access to the debt market through government-sponsored enterprises (GSEs), and the office and retail sectors, have the most debt offerings per firm. The health care ${ }^{8}$ and

\footnotetext{
${ }^{8}$ Health care sector include senior housing and assisted-living facilities.
} 
apartment sectors, which normally do not have long-term tenants, have the most equity offerings per firm. The sample for the 2004-2005 period had the highest issuing intensity in debt with three bond offerings per firm. Over the 2006 to 2008 period, there were more equity issues per firm (almost two issues per firm) then debt issues.

\section{[Put Table 3 here]}

The four panels in Table 3 report the summary statistics of measures of asset liquidation value by property type (panels $\mathrm{A}$ and $\mathrm{B}$ ) and by issuing year ( $\mathrm{C}$ and $\mathrm{D})$. Panels $\mathrm{A}$ and $\mathrm{C}$ describe the intrinsic measures of asset liquidation value of a REIT. For the intrinsic measures of liquidation value, the industry concentration ratios are stable over time, since those equilibrium industry structures tend to take effect over the long run. Diversified REITs have the highest concentration ratios (on average, 9.67\%) indicating that firms operating in markets in which industries are more concentrated tend to diversify their property types. The tenant quality declines over the period from 2000 to 2008, and then increases slightly in 2009. The health care sector has the lowest tenant Z-score (1.3) while the retail sector has the highest tenant Z-score (5-6). Panels B and D describe the market measures of asset liquidation value of a REIT. Cap rates decline over the 2000 to 2005 period and then rise from 2006 onwards, showing that the cap rate is forward-looking. For the market measures of liquidation value, the hotel sector has the highest cap rate and highest loss severity. It is consistent with the industry consensus that hotels are the riskiest asset class due to the lack of long-term tenants (e.g., many rent rooms for just one night). Apartments appear to have the lowest cap rate and loss severity.

\section{Empirical Analysis}

Based on the model of REIT liquidation value presented in Section 1 and empirical specifications of liquidation measures presented in Section 2, we test our four hypotheses by 
using multivariate logit regressions. Furthermore, we control for the common determinants of capital structure.

\subsection{Controlling Competitive Explanations}

To conduct our formal regression analysis, we control for determinants of financing choice that are commonly used in the capital structure literature: the effects of the trade-off theory (leverage ratio), the pecking order theory (profitability, growth opportunity), the market timing theory (market-to-book ratio), and signaling (dilution). Fixed costs associated with a new debt issue are lower for large firms, which makes debt financing more appealing to them. Therefore, we control for variables such as firm size, measured as the logarithm of a firm's book assets. We also consider alternative measures of these control variables for our robustness checks.

\subsubsection{Trade-off theory}

The trade-off theory, first proposed by Kraus and Litzenberger (1973), hypothesizes that firms weigh the benefits (e.g., tax savings) against the costs (e.g., deadweight bankruptcy costs) of debt, i.e., firms design each incremental financing activity to adjust their overall leverage ratios towards optimal target levels. Hence, they can gradually eliminate the deviations from the target. A firm in need of external finance should issue equity if its leverage ratio is above the target and issue debt if it is below. Thus, we control for the targeting behavior of corporate financing choice by using the leverage ratio of the firm. (For example, Flannery and Rangan, 2006, and Lewellen, 2006).

\subsubsection{Pecking order theory}

Myers and Majluf's (1984) pecking order theory states that when facing financing needs, firms prioritize their sources of financing. Internal funds are used first, and when those funds are depleted, the firm issues debt. When the debt capacity is reached, the firm issues 
equity.

Because profitable firms have a financial surplus, the pecking order theory predicts an inverse relation between profitability and leverage (Titman and Wessels, 1988; Fama and French, 2002). Profitable firms mainly use internal financing when necessary; hence their use of external sources of financing is low. The negative association between profitability and leverage that supports the pecking order theory has been empirically documented by Myers (1984), Baskin (1989), Friend and Lang (1988) and Rajan and Zingales (1995).

To control for the inverse relation between the profitability and leverage ratio, we include a measure of profitability, the return on average assets (ROAA). We also control for a firm's growth, which we measure as the growth rate of funds from operations (FFO). The FFO is a measure of REITs' operating performance that is calculated by adding depreciation and amortization expenses to earnings. FFO gives us a clearer idea of a REIT's cash performance, which is a better measure of the REIT's performance than is earnings.

\subsubsection{Market timing theory}

Baker and Wurgler (2002) explore the managers' practice of timing the equity market, and find evidence for this policy. They demonstrate that market timing implies that not only does the market-to-book ratio affect capital structure through equity issues, but also that the negative effect is persistent and helps to explain the cross-sectional variation in leverage. These effects cannot be explained by capital structure theories. We include the market-tobook ratio to control for the market timing effect.

\subsubsection{Signaling}

In the pecking order model, good-quality firms use internal funds to avoid the adverse selection problem and the loss of value. However, these firms are not able to signal their quality by using capital structure. Another strand of capital structure theory proposed by Ross (1977) posits that capital structure serves as a signal of private information. Ross's argu- 
ment is that equity issuance signals that the stock is overpriced. To avoid such a signaling effect, companies with major financing needs tend to prefer debt.

To control for the signaling effect, we include dilution as a control variable. We compute dilution as the total amount of new issues divided by total market cap one quarter prior to the security offering (Asquith and Mullins, 1986).

Table 4 summarizes the predicted effects on the firm's financing decisions.

$$
\text { [Put Table } 4 \text { here] }
$$

\subsection{The Results}

We use a univariate analysis to investigate the effect of liquidation value on financing choice. Table 5 summarizes the descriptive statistics of our measures of firms' liquidation values and the explanatory variables used in the multivariate analysis.

[Put Table 5 here]

The Pearson correlation matrix reported in Table 6 show that the correlations between these explanatory variables is moderate at best; most of the correlations are low for our primary variables of interests, especially tenant quality. For example, the correlations between tenant quality and the controls for alternative capital structure theories (leverage, profitability, market-to-book, dilution, FFO growth, and size) are within $\pm 8 \%$. The evidence supports our claim that tenant quality is a better proxy for liquidation value. The correlation between MSA industry concentration and tenant quality is -0.08 , which supports our empirical method of jointly testing short- and long-run measures of asset liquidation value. The correlation between tenant quality and the cap rate and loss severity are -0.20 and -0.13 , respectively. This result is not surprising, since the capital market captures some of information conveyed from intrinsic measures of asset quality.

[Put Table 6 here] 
In Table 7 , we compare the distributions of asset liquidation value measures and other explanatory variables and test for significant differences between debt offerings and equity offerings. The results suggest that on average, relative to REITs that issue equity, REITs that raise funds by issuing bonds have a larger market capitalization, lower current market leverage ratios, lower FFO growth, smaller offering amounts relative to the value of book assets, and higher market-to-book ratios.

$$
\text { [Put Table } 7 \text { here] }
$$

\subsubsection{Multivariate Logit Analysis}

We use multivariate logit regression analysis as our primary tool to study the choice of new security issuance. We set the dependent variable to one for bond issues and zero for equity issues. We measure the liquidation value with four different variables: the average tenant Z-scores, the industry concentration of top markets in which the REIT operates, the firm's capitalization rate, and the firm's loss severity from historical CMBS liquidation. According to our theoretical model, we expect a positive loading on the tenant quality and negative loadings on the other three measures.

Our control variables include the current market leverage ratio (Leverage), the return on average assets (Profitability), the market-to-book ratio, the offering amount divided by the market cap (Dilution), the growth rate of funds from operations (FFO growth), and logarithm of firm's book asset (firm size). Our empirical evidence, which is consistent across all four measures of liquidation value, supports the Shleifer and Vishny (1992) hypothesis. Firms that issue bonds not only have higher quality tenants (Z-scores) but also hold assets in real estate markets that tend to have a more diverse mix of industries in a location relative to the industry concentration associated with equity-offering firms. The relation is reversed for the capitalization rate and the historical loss severity. These results suggest that higher expected liquidation values are associated with a higher likelihood of bond issues relative to 
equity issues. The effect is significant from both statistical and economic perspectives. A one-standard-deviation increase in the tenant quality is associated with a $5 \%$ to $7 \%$ higher probability of issuing debt. The probability increases are about $5 \%$ and $3 \%$ for a onestandard-deviation decrease in the cap rate and the loss severity rate, respectively.

\section{[Put Table 8 here]}

Table 8 presents the multivariate logit regression results with intrinsic measures of asset liquidation value. Model 1 tests the effects of asset liquidation value using MSA industry concentration and tenant quality, but does so without controlling proxies for other capital structure theories. The two intrinsic measures are positively associated with a REIT's decision to issue debt. The higher the asset liquidation value (lower industry concentration and higher tenant quality), the greater the likelihood of debt issuance. The results are statistically significant at the $1 \%$ level.

The column "Change in Prob" in model 1, which computes the change in probability of issuing debt for a one-standard-deviation increase in a corresponding variable, also shows the economic significance. A one-standard-deviation increase (decrease) in the tenant average Z-score (industry concentration ratio of REIT's top markets) is associated with a 5\% (6\%) higher probability that a firm will issue debt. In addition, the firm's characteristics also play an important role in its financing decisions. Larger firms are more likely to issue debt.

In Model 2 we include the average lease maturity as an additional control. Given tenant quality, the lease maturity has no effect on a firm's financing choice, which verifies our hypothesis that lease maturity is endogenously determined.

Model 3 further controls for alternative capital structure theories. Our results are consistent with the trade-off, pecking order, and signaling theories of capital structure. The market leverage prior to a new security issue has a significant negative impact on the use of bonds. This finding is consistent with the trade-off theory. Our estimates suggest that given 
a one-standard-deviation increase in market leverage, on average a firm is $15 \%$ less likely to issue bonds. Consistent with the pecking order theory, there is a negative relation between debt financing and the FFO growth or profitability ratio. Our estimates are also consistent with the signaling hypothesis, under which the firm's likelihood of issuing debt increases by $5 \%$ if the dilution measure increases by one standard deviation. Conditional on these four theories, our proxies for asset liquidation value remain significant on both a statistical and economical basis.

[Put Table 9 here]

Using the firm-level cap rate and loss severity rate as explanatory variables, in models 4 and 5 in Table 9 we test the effects of financing choice by using each of the two market measures of liquidation value separately. Given proxies for trade-off, pecking order, market timing, and signaling theory, the firm's market measures of asset liquidation value remain significant. A one-standard-deviation increase in the firm's cap rate (loss severity rate) is associated with a $5 \%(3 \%)$ decrease in the probability of issuing debt.

\subsubsection{Robustness Checks}

To check if tenant quality is a main driver of asset liquidation value, which in turn determines a firm's financing choice, we perform several robustness tests. We first check the model specifications 1,2 , and 3 with a tighter sample under sample selection criterion 1 . Table 10 shows that the results are consistent with those in Table 8. Tenant quality remains a significant driver of a firm's financing choice in this sample, which comprises 863 observations. Other control variables have similar results, except for the dilution factor, which becomes nonsignificant. The overall fit improves for model 3. Although the sample size is reduced by $17 \%$, with the same number of regressors the pseudo $R^{2}$ increases from $19.7 \%$ (Table 8 Model 3) to $21.1 \%$ (Table 10 Model 3). 
[Put Table 10 here]

In Table 11 we examine the model specifications 4 and 5 with a larger sample under selection criterion 3 . The sample, which comprises $1,448(1,300)$ observations, contains all security offerings, in which we can compute both the cap rate (loss severity) and other control variables. The two samples are much larger than those in the baseline regression (Table 9 , models 4 and 5), but the results are consistent with the baseline results. A one-standarddeviation decrease in the cap rate (loss severity rate) is associated with a $4 \%$ (5\%) increase in the probability of issuing debt. The results become statistically significant at the $1 \%$ level.

[Put table 11 here]

In Table 12 we explore the financing decision of firms such as hotels, apartments, selfstorage, etc. that do not have long-term tenants. Without tenant information, an intrinsic measure of asset liquidation value is not possible. We compare the financing effects of market measures of liquidation value derived from the cap rate and the loss severity rate. Model 4 in Table 12 shows that the cap rate is significant and negatively associated with the probability of issuing debt. A one-standard-deviation decrease in the cap rate implies a $9 \%$ higher probability of issuing debt. This sensitivity is almost twice as large as the magnitude in the baseline sample.

Model 5 in the Table 12 shows that a one-standard deviation decrease in the loss severity measure is associated with a $16 \%$ higher probability of issuing debt. This sensitivity is more than five times as large as the magnitude in the baseline regression.

The results in the Table 12 indicate that when we cannot directly observe the intrinsic measures of asset quality, the firm's financing choice relies more heavily on market indicators. If we interpret the magnitude of the coefficient of the cap rate (or loss severity rate) as the sensitivity of the firm's financing choice to market indicators, then the sensitivities are two 
to five times as large as those that have an intrinsic (or direct) measure of the firm's asset liquidation value.

[Put Table 12 here]

The results in Table 8 to Table 12 show that, overall, our results are robust to model specifications. Both intrinsic and market measures of liquidation value have a significant impact on a firm's financing choice.

\section{Conclusion}

To test the Shleifer and Vishny (1992) hypothesis that the asset liquidation value influences a firm's financing choices, we focus on asset quality. The real estate industry provides an ideal setting to test the cross-sectional patterns of firms' financing choices, since the value of real assets is relatively easier to identify and measure. In this setting, asset quality not only encompasses the quality of the tenants who occupy the building, but also the location quality of an area. To determine location quality we use its economic base (mixture of various industries) as a proxy, since real estate is fixed in location and the health of the local economy influences the cash flow of the tenants. Our tenant quality measure reflects the asset quality from a shorter-term perspective. Since our metric of industry concentration (economic base) within local markets captures the long-term redeployability notion of Benmelech, Garmaise, and Moskowitz (2005), we essentially control for such long-term equilibrium vis-à-vis the industry concentration.

We construct a valuation model to determine the factors that should influence liquidation value and financing choice. We then test whether our model predicts the observed choices that firms make in terms of their choice to issue debt or equity. We find that as predicted,

firms with low asset liquidation values are less likely to issue debt to raise additional funds. When controlling for traditional factors that explain firm financing decision, we still find 
significant evidence that supports Shleifer and Vishny's hypothesis. Asset quality is an important determinant of both liquidation value and debt capacity. Firms that issue debt not only have higher quality tenants, but also hold assets in geographical markets that have a more diverse mix of industries relative to firms that issue equity. For firms such as hotels, apartments and self-storage, whose assets are not occupied by long-term tenants we cannot easily observe the fundamental measures of asset quality. The firm's financing choices rely more heavily on the overall real asset market conditions in these situations.

\section{References}

[1] Altman, E. 1968, Financial Ratios, Discriminant Analysis and the Prediction of Corporate Bankruptcy, Journal of Finance, September 1968;

[2] Altman, Edward I. 2002. Revisiting Credit Scoring Models in a Basel II Environment. Prepared for "Credit Rating: Methodologies, Rationale, and Default Risk", London Risk Books 2002.

[3] Asquith, Paul and David W. Mullins, Jr., 1986, Equity Issues and Offering Dilution, Journal of Financial Economics 15, 61-89.

[4] Baker, M. and Wurgler, J., (2002), Market Timing and Capital Structure, The Journal of Finance 62, 1-32.

[5] Baskin J., (1989), An Empirical Investigation Of The Pecking Order Hypothesis, Financial Management, vol. 18, pp. 26-35.

[6] Benmelech, E, (2009), Asset Salability and Debt Maturity: Evidence from Nineteenth-Century American Railroads, Review of Financial Studies 22(4):1545-1584.

[7] Benmelech, E., and Nittai K. Bergman, (2008), Liquidation Values and the Credibility of Financial Contract Renegotiation: Evidence from U.S. Airlines, Quarterly Journal of Economics, 123(4) 1635-1677. 
[8] Benmelech, E., M.J. Garmaise, and T.J. Moskowitz, (2005), Do Liquidation Values Affect Financial Contract? Evidence from Commercial Loan Contracts and Zoning Regulation. Quarterly Journal of Economics. 120, 1121-1154.

[9] Capozza, D. R., and P. Seguin. (1998b). Focus Transparency and Value, Real Estate Economics $27(4), 587-619$.

[10] Chaney, T. , D. Sraer, and D. Thesmar, 2010, The Collateral Channel: How Real Estate Shocks affect Corporate Investment, National Bureau of Economic Research Working Paper 16060.

[11] Campello, M., and Giambona, E., 2010, The Capital Structure and Redeployability of Tangible Assets, University of Illinois Working Paper.

[12] Fama E.F., and K.R. French, (2002), Testing Tradeoff and Pecking Order Predictions About Dividends and Debt, Review of Financial Studies, Vol. 15, Iss. 1, pp. 1-43.

[13] Flannery, M.J., and Rangan, K.P., (2006), Partial Adjustment Toward Target Capital Structures, Journal of Financial Economics, Vol. 79, Iss. 3, pp. 469-506.

[14] Friend I., and Lang, L.H.P., (1988), An Empirical Test of the Impact of Managerial Self-interest on Corporate Capital Structure, Journal of Finance, Vol. 43, pp. 271-281.

[15] Giambona, E., Harding, J.P., and Sirmans, C.F., (2008), Explaining the Variation in REIT Capital Structure: The Role of Asset Liquidation Value, Real Estate Economics, vol. 36, iss. 1, pp111-137.

[16] Hirschman, A. O. (1964), The Paternity of an Index, The American Economic Review 54 (5): 761.

[17] Hou K., (2007), Industry Information Diffusion and the Lead-Lag Effect in Stock Returns. Review of Financial Studies, Vol. 20, pp. 1113-1138. 
[18] Kaplan, S.N., (1989), Campeau's Acquisition of Federated: Value Destroyed or Value Added? Journal of Financial Economics 25, pp. 191-212.

[19] Kraus, A., and Litzenberger, R.H., (1973), A State-Preference Model of Optimal Financial Leverage, The Journal of Finance, Vol. 28, pp. 911-922.

[20] Lemmon, M.L. and Roberts, M.R. and Zender, J.F., (2008), Back to the Beginning: Persistence and the Cross-section of Corporate Capital Structure, The Journal of Finance, Vol. 63, pp. $1575-1608$.

[21] Lewellen, J., (2006), Financing Decisions when Managers are Risk Averse, Journal of Financial Economics, Vol. 82, Iss. 3, pp. 551-589.

[22] Myers, Stewart C., (1984), The Capital Structure Puzzle, Journal of Finance 39, 575-592.

[23] Myers, Stewart C. and Majluf, Nicholas S., (1984), Corporate Financing and Investment Decisions When Firms Have InformationThat Investors Do Not Have, Journal of Financial Economics 13, pp.187-222.

[24] Plazzi, A., Torous, W. and Valkanov, R. (2010), Expected Returns and the Expected Growth in Rents in Commercial Real Estate, Review of Financial Studies Vol 23, Issue 9, pp. 34693519.

[25] Rajan R.G., and Zingales, L., (1995), What Do We Know About Capital Structure? Some Evidence from International Data, The Journal of Finance, Vol. 50, pp. 1421-1460.

[26] Shleifer, A., and Vishny, R., (1992), Liquidation Values and Debt Capacity: A Market Equilibrium Approach, The Journal of Finance, Vol. 47, iss. 4, pp. 1343-1366.

[27] Smith, Gavin, (2009), Commercial Real Estate: Scoring the Risk of Office, Retail, and Industrial tenants, The RMA Journal Dec. 2009 - Jan. 2010 pp.50-60. 
[28] Sibilkov, Valeriy, Oct 2009. "Asset Liquidity and Capital Structure" Journal of Financial and Quantitative Analysis 44(05): 1173-1196.

[29] Strebulaev, I.A., (2007), Do Tests of Capital Structure Theory Mean What They Say? The Journal of Finance, vol. 62, pp.1747-1787.

[30] Titman, S., (1983), The Effect of Capital Structure on a Firm's Liquidation Decision, Journal of Financial Economics Vol 13, Issue 1, pp. 137-151.

[31] Titman, S., Wessels, R., (1988), The Determinants of Capital Structure. Journal of Finance Vol 43, pp. 1-19. 


\section{Appendix: Model with Cash Flow Growth}

In Section 1, we assume that the firm generates a constant cash flow. We extend the basic model by introducing cash flow growth. Under the cash flow growth model, we prove that the negative relation between the capitalization rate and firm's liquidation value remains true.

Assuming the firm's cash flow grows at a constant rate $g$, then Equations (1) and (2) become

$$
V_{0}=E_{0}\left[\int_{0}^{\tau_{\lambda}} e^{-r t} e^{g t} I d t+e^{-r \tau_{\lambda}} V_{1}\right]
$$

and

$$
V_{1}=E_{0}\left[\int_{0}^{\tau_{\lambda}^{\prime}} e^{-r t}\left(1-\beta e^{-\kappa t}\right) e^{g t} I d t+e^{-r \tau_{\lambda}^{\prime}} V_{1}\right],
$$

which lead Equations (3) and (4) to

$$
V_{1}=\frac{I}{r}(r+\lambda)\left(\frac{1}{r-g+\lambda}-\beta \frac{1}{r-g+\lambda+\kappa}\right)
$$

and

$$
V_{0}=\frac{I}{r-g+\lambda}+\frac{\lambda}{r+\lambda} V_{1} .
$$

Plugging in cap rate $C=\frac{I}{V_{0}}$, the normalized firm liquidation value becomes

$$
L=\left(1+\frac{r}{\lambda}\right)\left(1-\frac{C}{r-g+\lambda}\right)
$$

It is straightforward to show $\frac{\partial L}{\partial C}<0$, which confirms the Section 1's prediction of a negative relation between the cap rate and firm's liquidation value. 


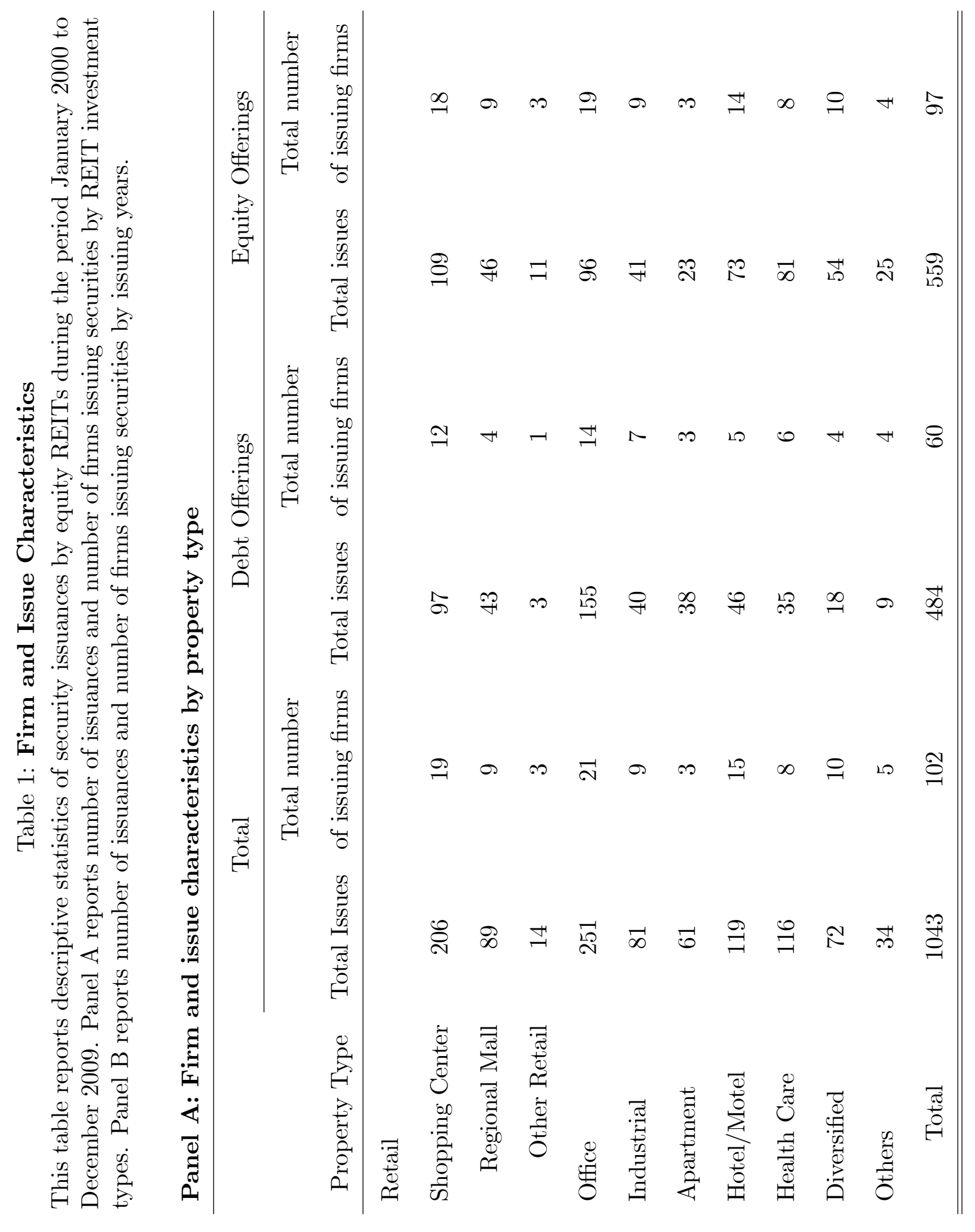




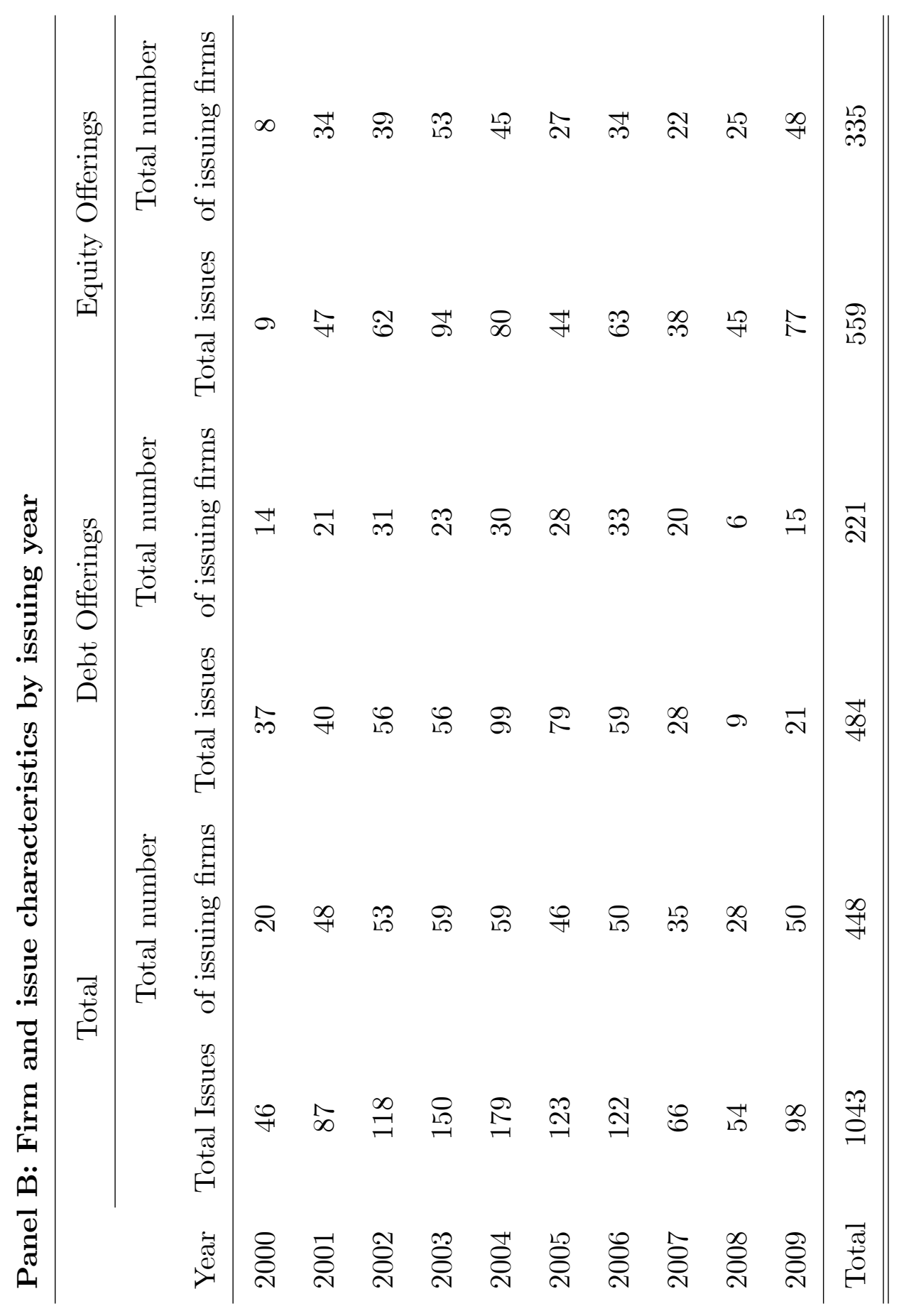




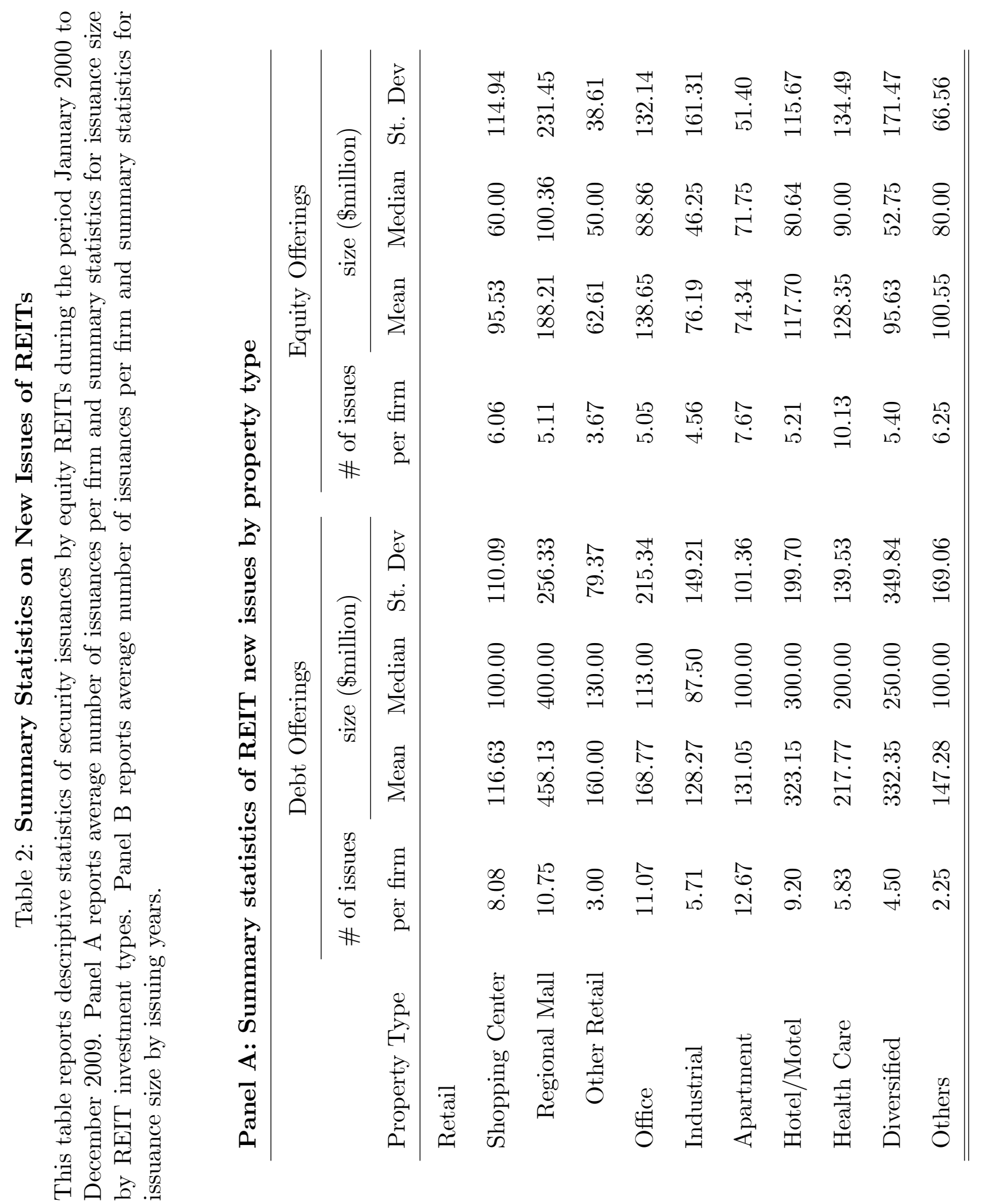




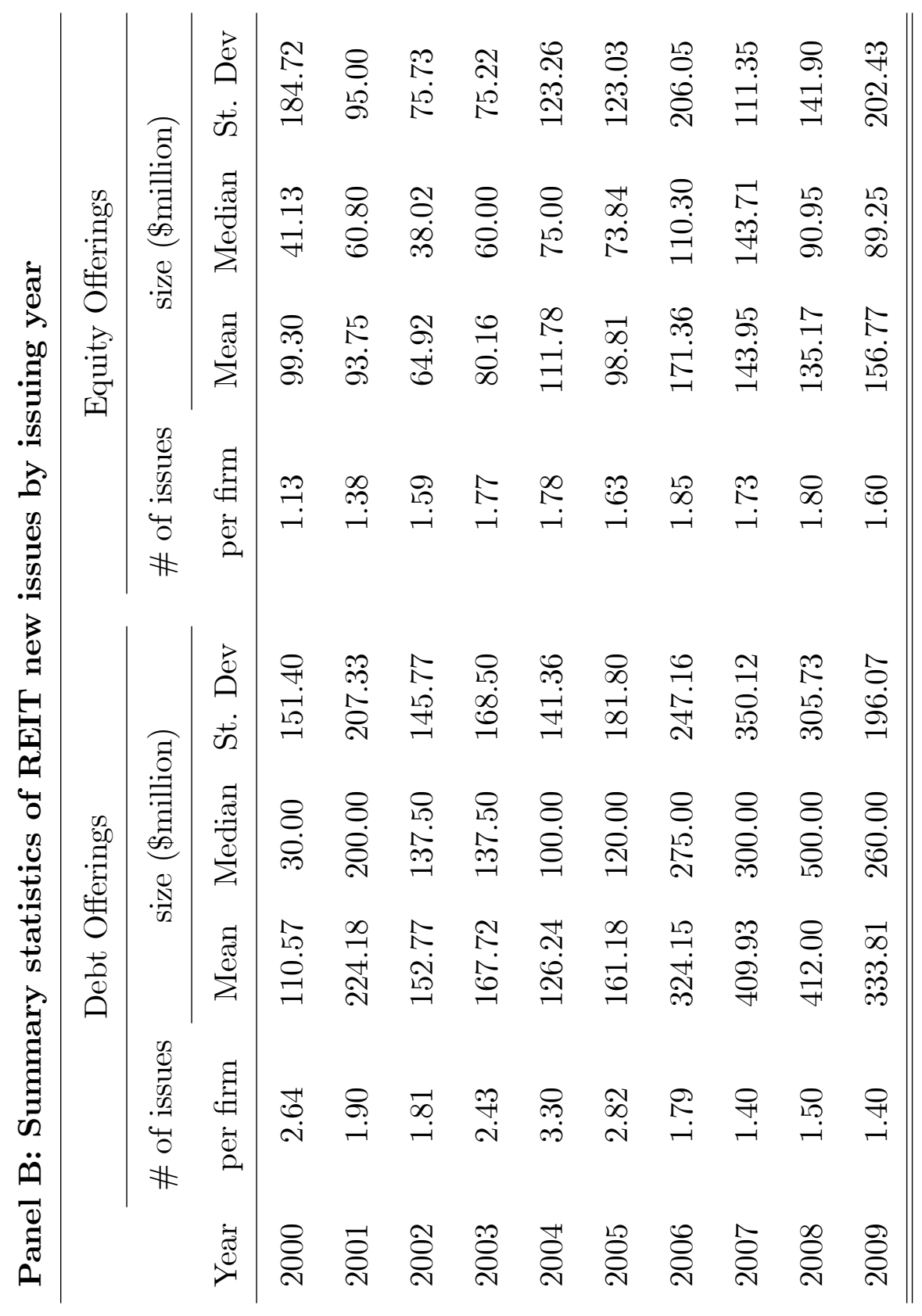




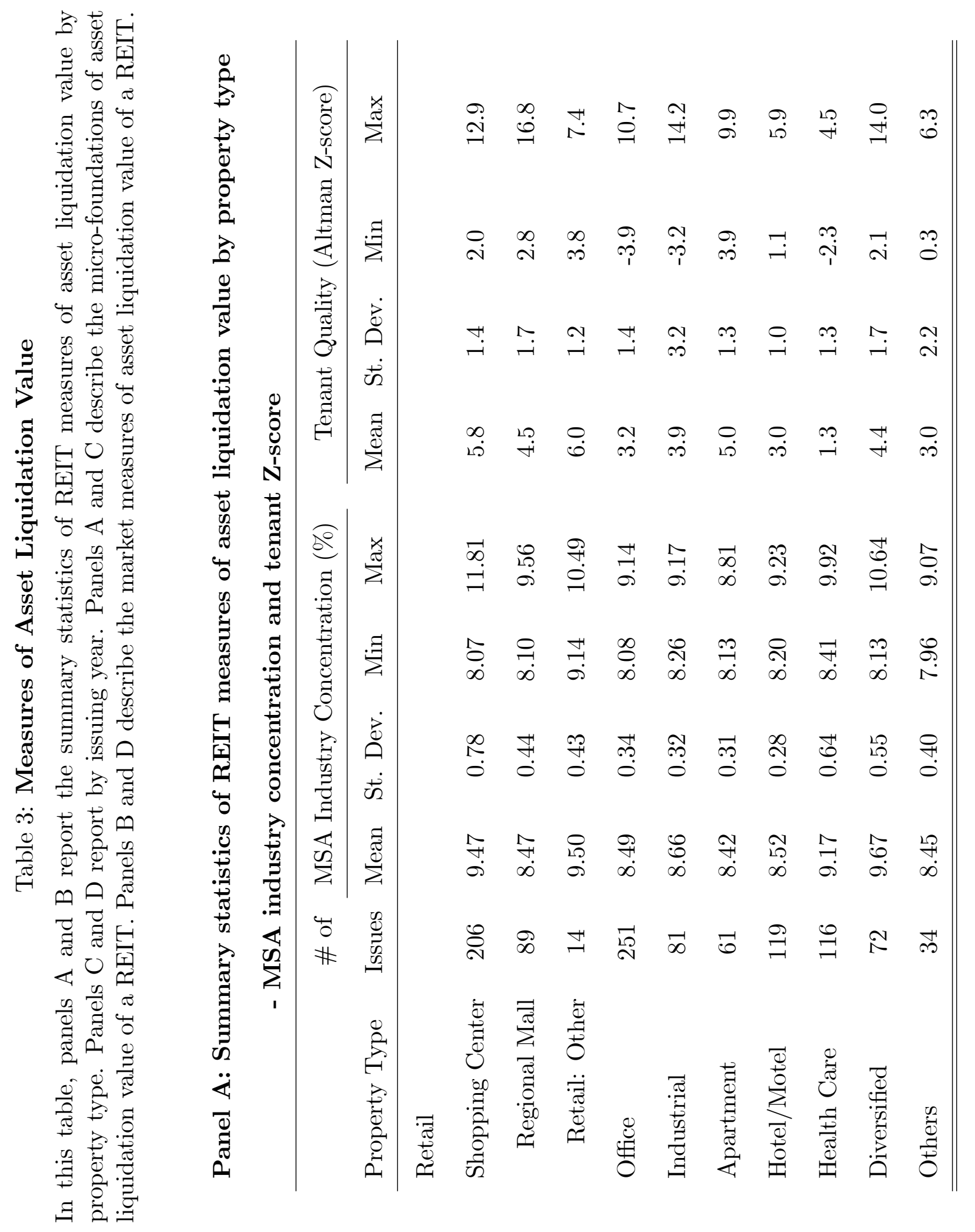




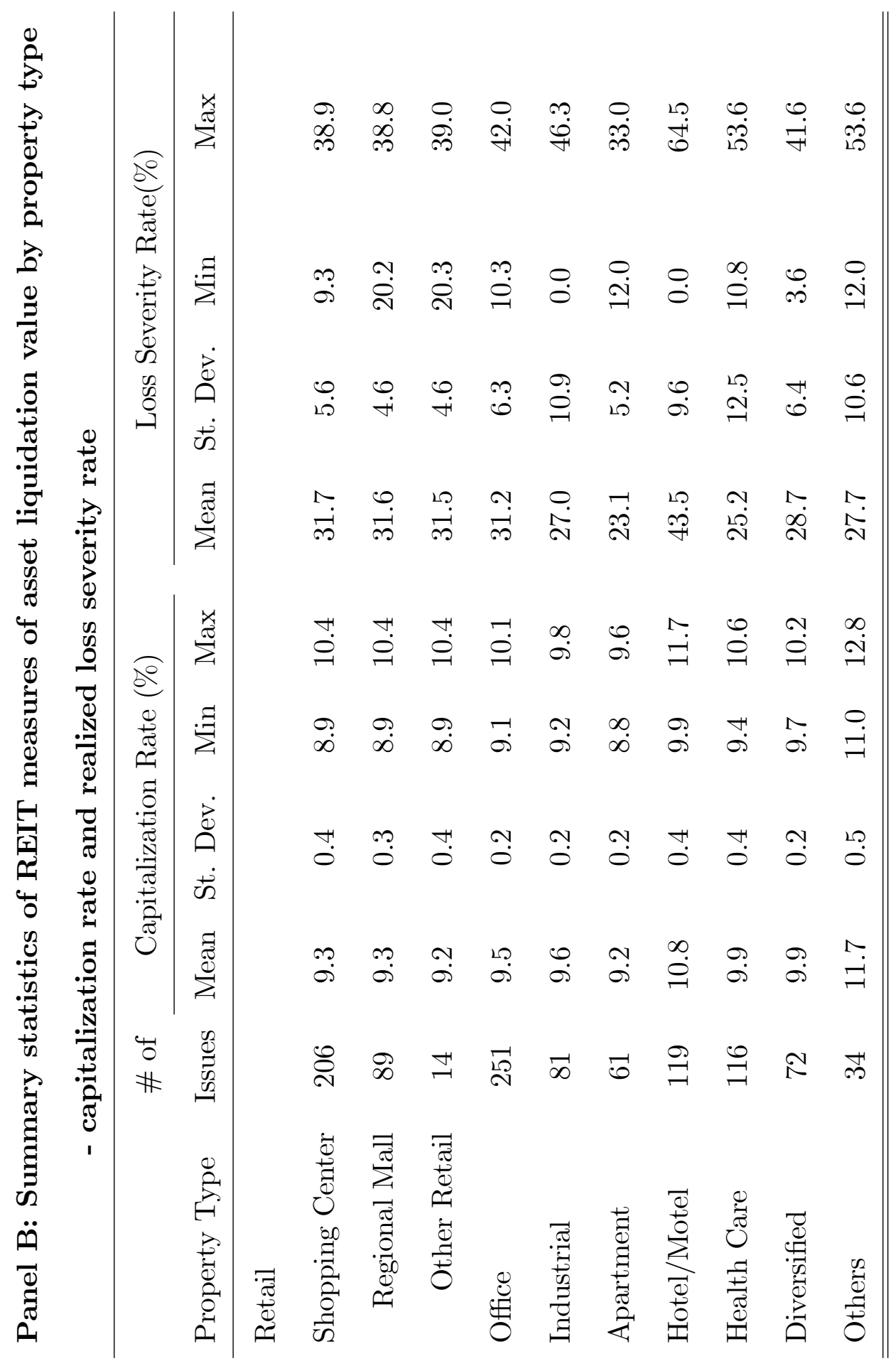




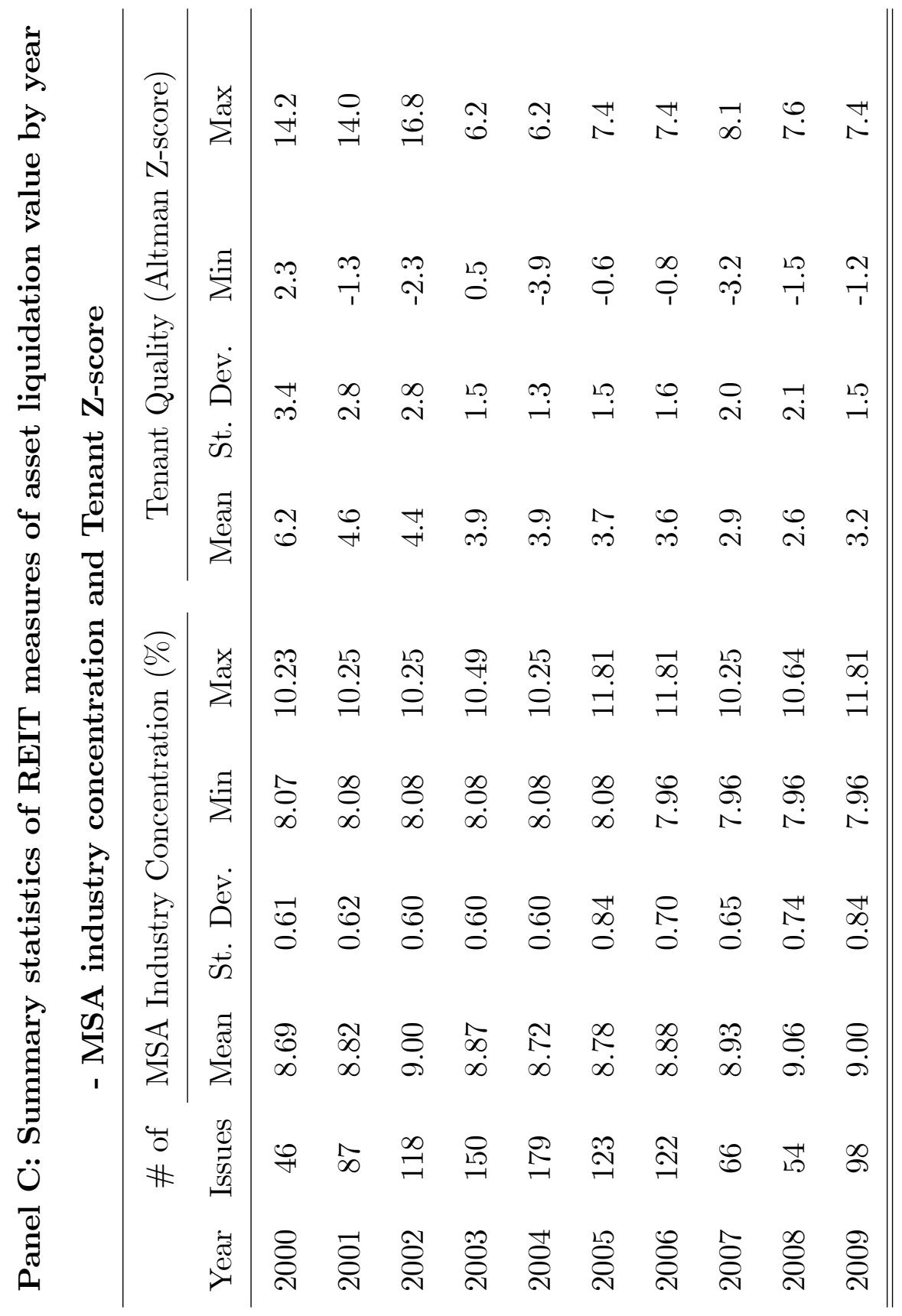




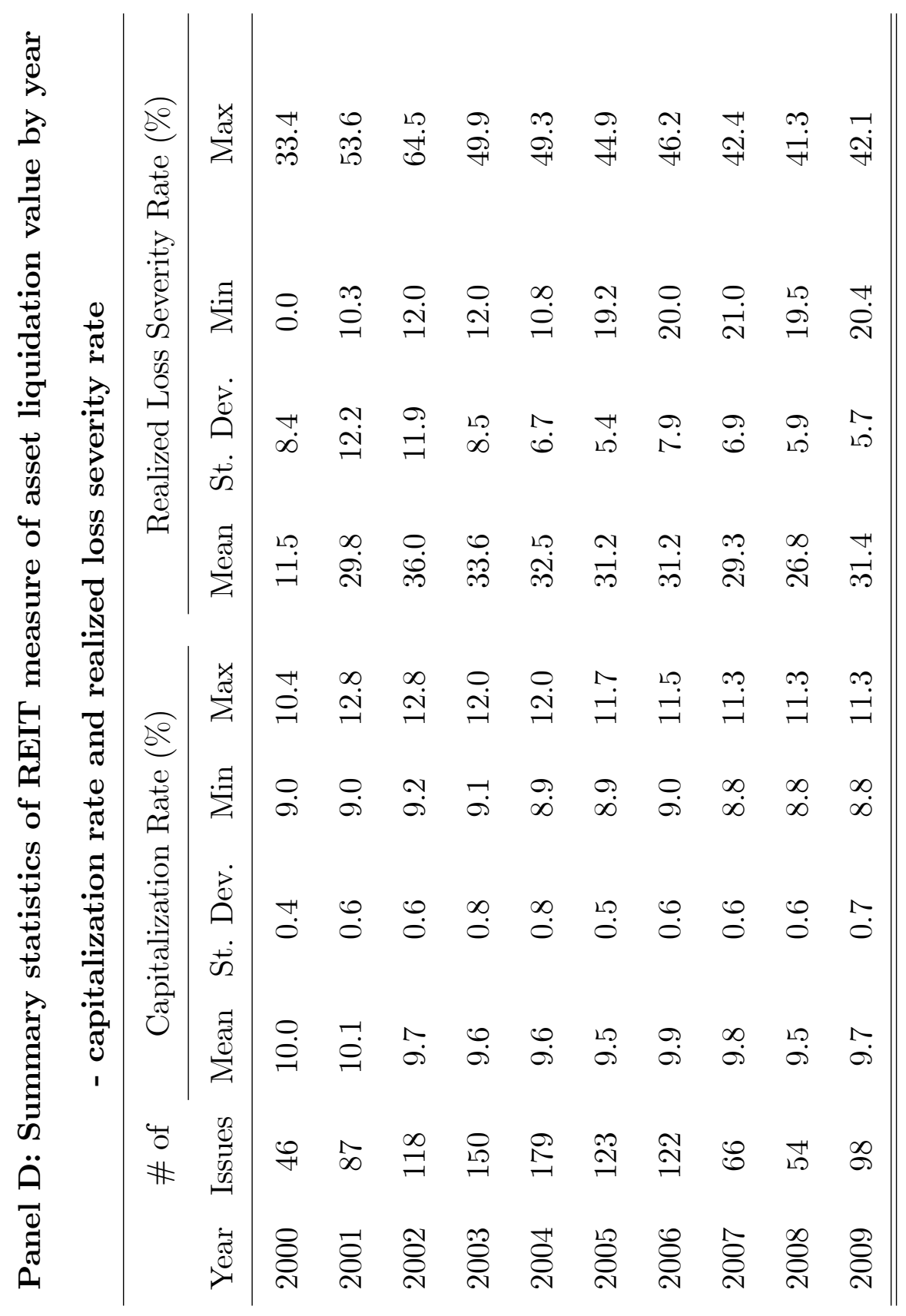




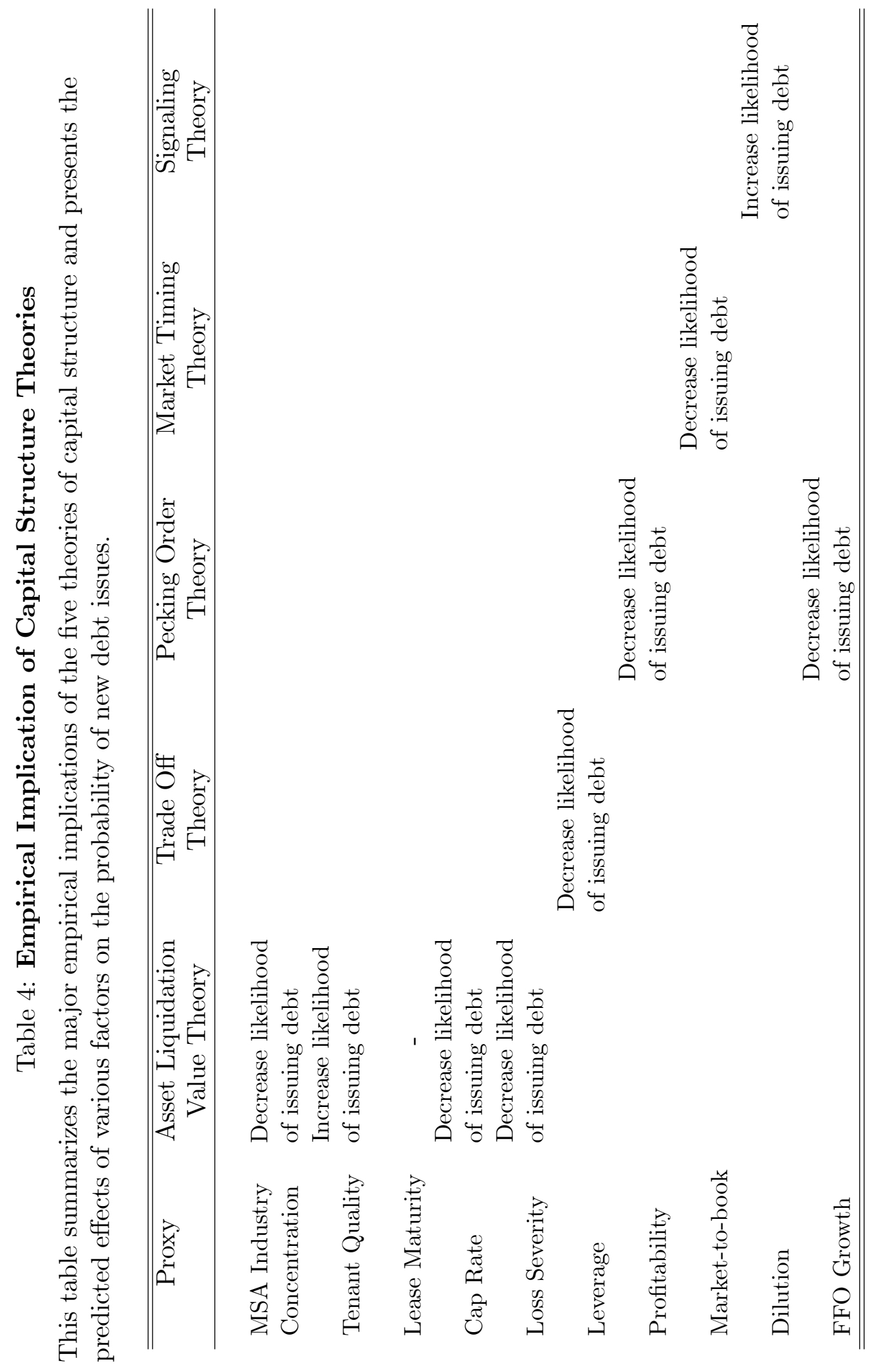




\section{Table 5: Descriptive Statistics}

This table reports the summary statistics of the independent variables of REIT security issuance decisions for the sample of 1,043 observations.

\begin{tabular}{lccccc}
\hline \hline Variable & Observation & Mean & Std. Dev. & Min & Max \\
\hline & & & & & \\
MSA Industry concentration (\%) & 1043 & 8.86 & 0.69 & 7.96 & 11.81 \\
Tenant Quality (Altman Z-score) & 1043 & 3.87 & 2.12 & -3.87 & 16.81 \\
Lease Maturity (years) & 1043 & 3.88 & 1.69 & 0.00 & 5.56 \\
Cap Rate (\%) & 1043 & 9.71 & 0.68 & 8.77 & 12.76 \\
Loss Severity (\%) & 1043 & 30.99 & 9.48 & 0.00 & 64.53 \\
Leverage Ratio & 1043 & 0.48 & 0.13 & 0.09 & 0.97 \\
Profitability (\%) & 1043 & 3.50 & 4.36 & -8.11 & 76.57 \\
Market-to-book & 1043 & 1.14 & 0.24 & 0.56 & 1.78 \\
Dilution & 1043 & 0.10 & 0.16 & 0.00 & 3.09 \\
FFO Growth (\%) & 1043 & 9.87 & 32.98 & -96.57 & 185.92 \\
Size & 1043 & 14.91 & 1.14 & 9.55 & 17.20 \\
\hline \hline
\end{tabular}




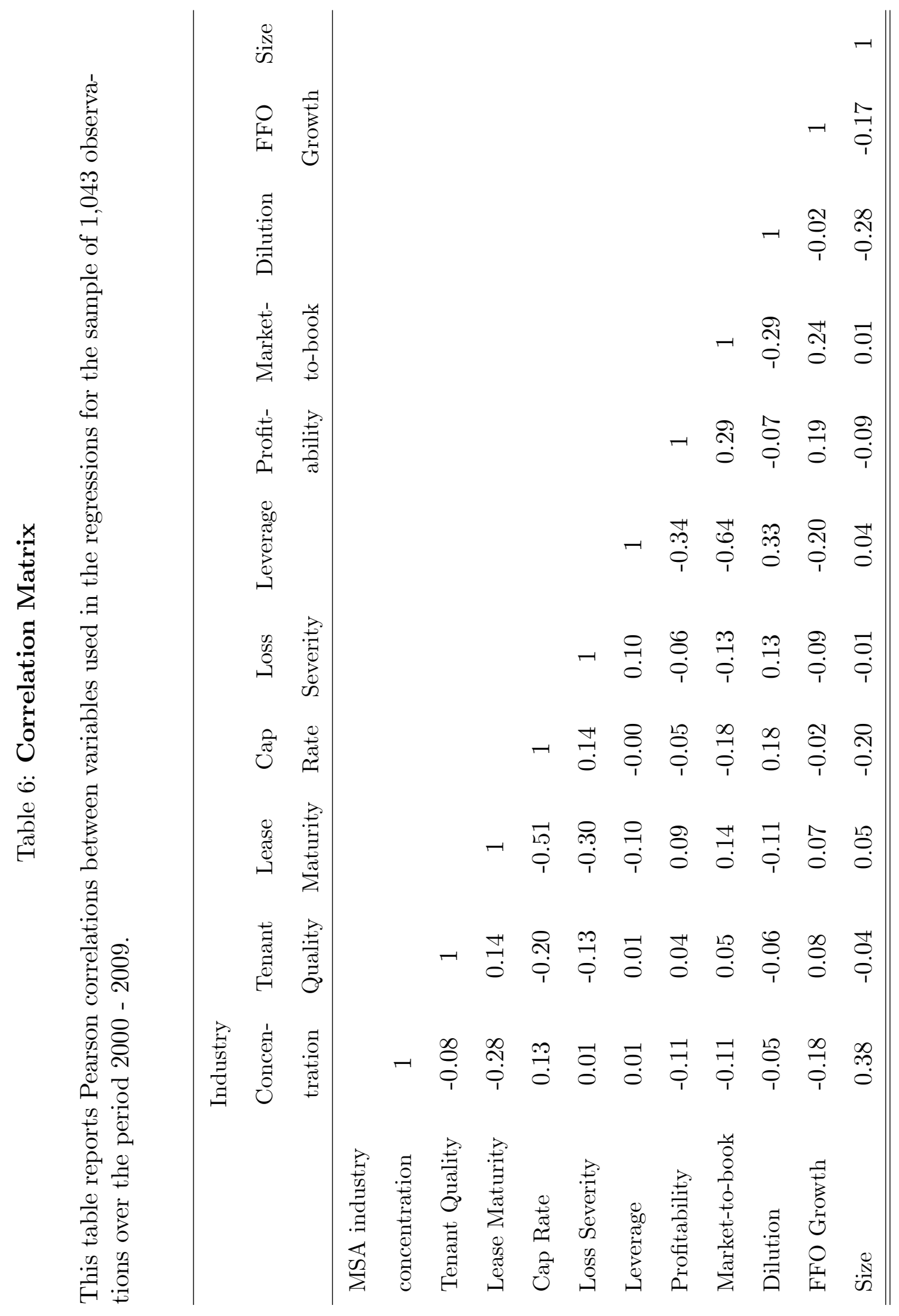




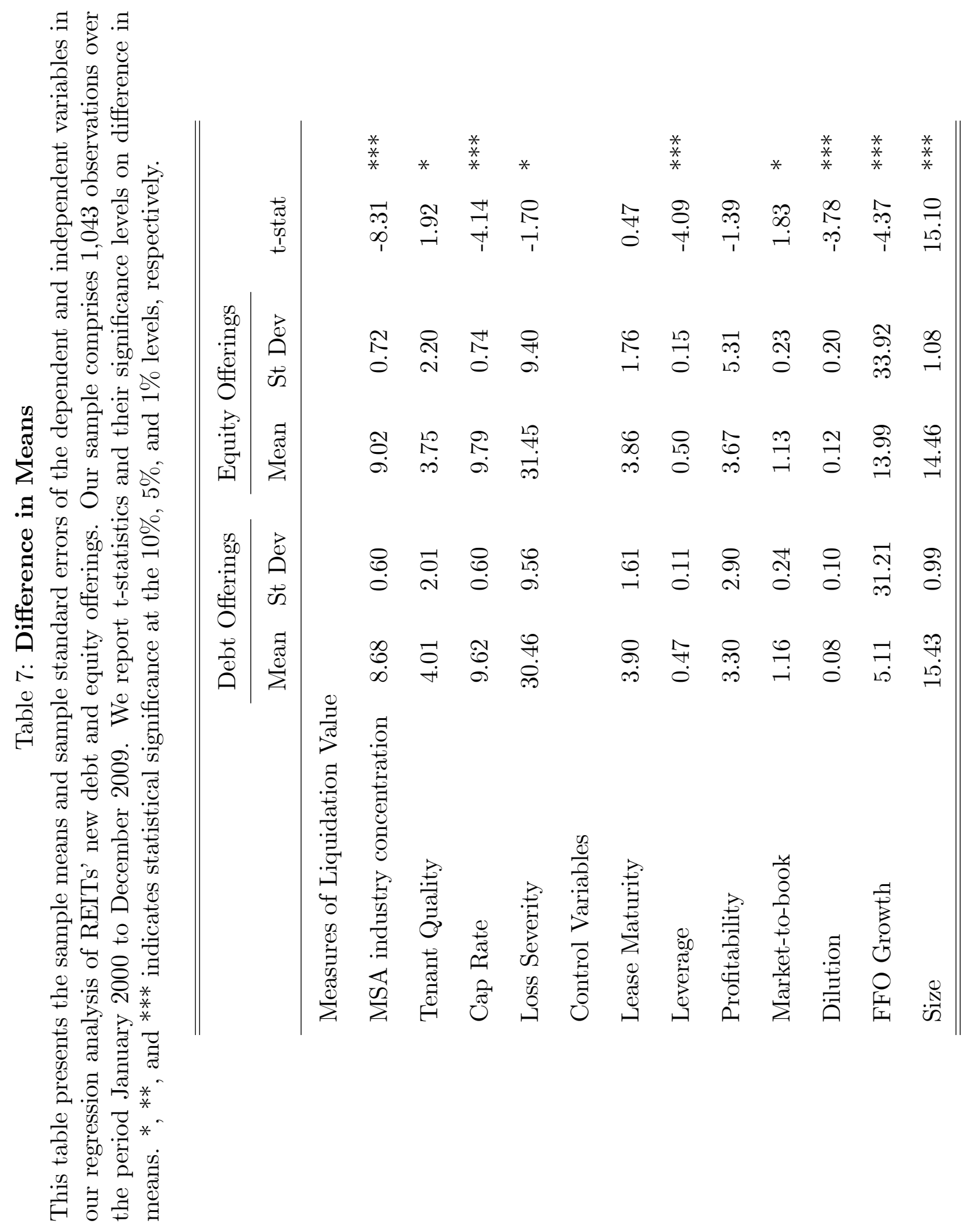


Table 8: Logit Regression Results with Intrinsic Measures of REIT Liquidation Value (Sample Selection Criterion 2)

This table presents the multivariate logit regression results we obtain for REITs' incremental financing decisions. Our sample comprises 1,043 observations selected under sample selection criterion 2. We include additional observations if REIT properties are managed by a public operator or have mixed use. The dependent variable is set to one for a new bond issue, and zero for an equity issue. We measure liquidation value by the industry concentration ratio of REIT top markets and the revenue-weighted average Altman Z-score of major tenants. Leverage is the ratio of total debt to total market assets, where we define market assets as the total book assets plus the difference between the market value of equity and the book value of equity. The growth rate of funds from operations (FFO Growth) is the annual percentage change in such funds. Dilution is the total amount of offering divided by the market cap prior to the new issue. We measure profitability by the return on average assets (ROAA). Market-to-book is the total book assets divided by the total market value of assets. Z-statistics are shown in the line below the coefficient. *, **, and *** indicate statistical significance at the $10 \%, 5 \%$, and $1 \%$ levels, respectively.

\begin{tabular}{|c|c|c|c|c|c|c|}
\hline \multirow{3}{*}{$\begin{array}{r} \\
\text { Measures of } \\
\text { Liquidation Value }\end{array}$} & \multicolumn{2}{|c|}{ Model 1} & \multicolumn{2}{|c|}{ Model 2} & \multicolumn{2}{|c|}{ Model 3} \\
\hline & Coefficient & $\begin{array}{l}\text { Change } \\
\text { in Prob. }\end{array}$ & Coefficient & $\begin{array}{l}\text { Change } \\
\text { in Prob. }\end{array}$ & Coefficient & $\begin{array}{l}\text { Change } \\
\text { in Prob. }\end{array}$ \\
\hline & & & & & & \\
\hline MSA Industry & $-0.362^{* * *}$ & $-6.1 \%$ & $-0.384^{* * *}$ & $-6.4 \%$ & $-0.274^{* *}$ & $-4.6 \%$ \\
\hline Concentration & -3.177 & & -3.153 & & -2.116 & \\
\hline Tenant Quality & $\begin{array}{l}0.095^{\text {*** }} \\
2.949\end{array}$ & $5.0 \%$ & $\begin{array}{l}0.093^{\text {*** }} \\
2.868\end{array}$ & $4.9 \%$ & $\begin{array}{l}0.119^{* * *} \\
3.547\end{array}$ & $6.3 \%$ \\
\hline Control Variables & & & & & & \\
\hline Lease Maturity & & & $\begin{array}{c}0.023 \\
0.520\end{array}$ & $0.9 \%$ & $\begin{array}{c}0.001 \\
0.045\end{array}$ & $0.0 \%$ \\
\hline Leverage & & & & & $\begin{array}{l}-4.805^{* * *} \\
-5.943\end{array}$ & $-14.4 \%$ \\
\hline Profitability & & & & & $\begin{array}{l}-0.027 \\
-1.341\end{array}$ & $-2.9 \%$ \\
\hline Market-to-book & & & & & $\begin{array}{l}-0.339 \\
-0.836\end{array}$ & $-2.0 \%$ \\
\hline Dilution & & & & & $\begin{array}{l}1.208^{* *} \\
2.339\end{array}$ & $4.9 \%$ \\
\hline FFO Growth & & & & & $\begin{array}{l}-0.008^{* * *} \\
-3.129\end{array}$ & $-6.4 \%$ \\
\hline Size & $\begin{array}{c}0.902^{* * *} \\
10.890\end{array}$ & $24.6 \%$ & $\begin{array}{l}0.896^{* * *} \\
10.690\end{array}$ & $24.4 \%$ & $\begin{array}{l}1.029^{* * * *} \\
11.000\end{array}$ & $27.7 \%$ \\
\hline Intercept & $\begin{array}{l}-10.800^{* * *} \\
-5.977\end{array}$ & & $\begin{array}{l}-10.580^{* * *} \\
-5.712\end{array}$ & & $\begin{array}{c}-10.830^{* * *} \\
-5.420\end{array}$ & \\
\hline Pseudo $R^{2}$ & 0.1 & & 0.1 & & 0.1 & \\
\hline Log Likelihood & -60 & & -60 & & $-57 \varepsilon$ & \\
\hline Observations & 10 & & 10 & & 10 & \\
\hline
\end{tabular}




\section{Table 9: Logit Regression Results with Market Measures of REIT Liquidiation Value (Sample Selection Criterion 2)}

This table presents the multivariate logit regression results we obtain for REITs' incremental financing decisions. Our sample comprises 1,043 observations selected under sample selection criterion 2 . We include additional observations if REIT properties are managed by a public operator or have mixed use. The dependent variable is set to one for a new bond issue, and zero for an equity issue. We measure liquidation value separately by using the self-constructed firm level capitalization rate and firm level realized loss severity rate. Leverage is the ratio of total debt to total market assets, where we define market assets as the total book assets plus the difference between the market value of equity and the book value of equity. Funds from operations (FFO) growth is the annual percentage change in such funds. Dilution is the total amount of the offering divided by the market cap prior to the new issue. We measure profitability by the return on average assets (ROAA). Market-to-book is the total book assets divided by the total market value of assets. Z-statistics are shown below the coefficient. ${ }^{*}, * *$, and ${ }^{* * *}$ indicate statistical significance at the $10 \%, 5 \%$, and $1 \%$ levels, respectively.

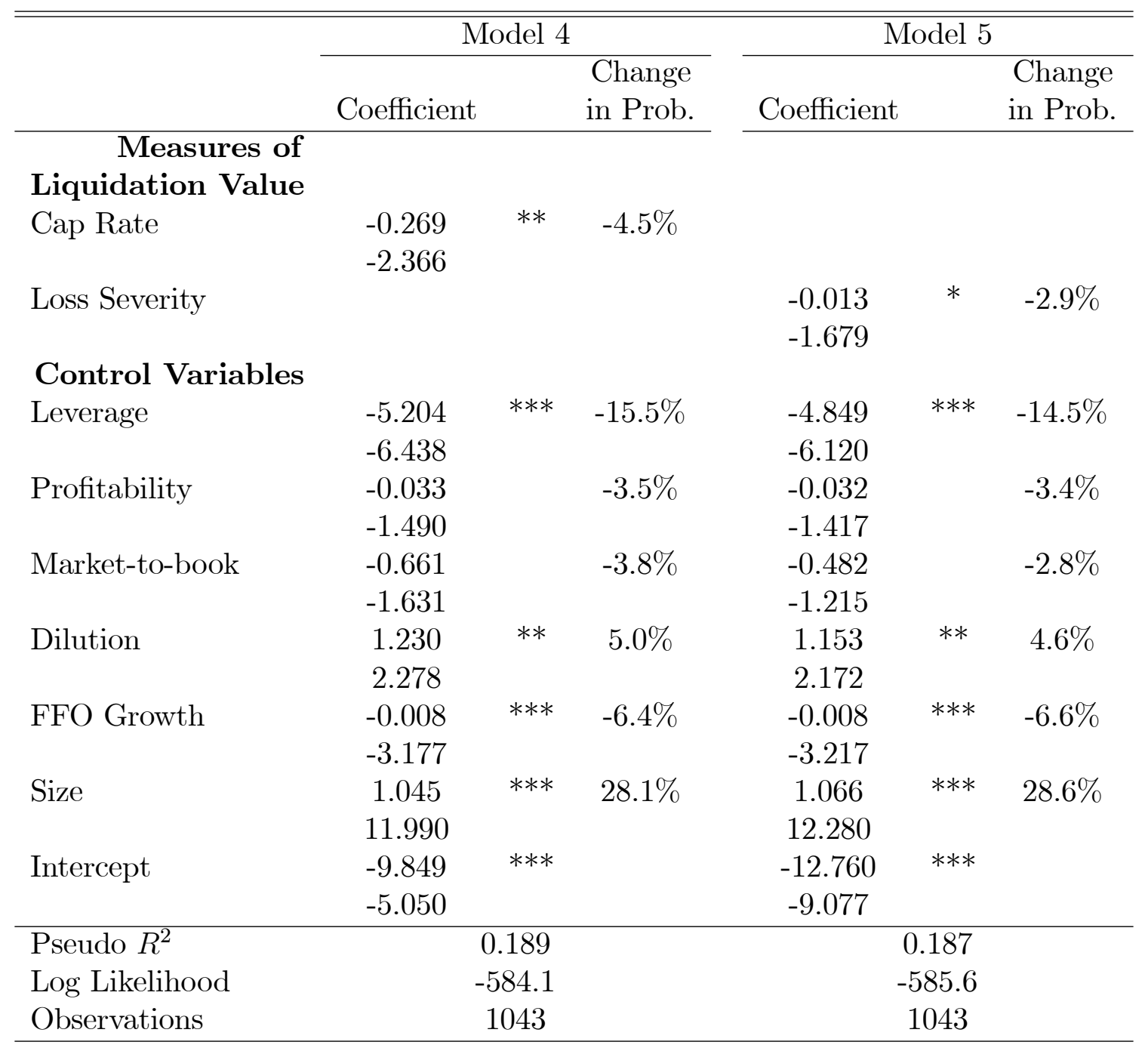




\section{Table 10: Robustness Check - Regression Results with Intrinsic Measures of REIT Liquidation Value (Sample Selection Criterion 1)}

This table presents the multivariate logit regression results of REITs' incremental financing decisions for a sample of 863 observations selected under sample selection criterion 1 . We remove observations if any one of the four liquidation measures is missing. The dependent variable is set to one for a new bond issue, and zero for an equity issue. We measure liquidation value by the industry concentration ratio of REIT top markets and revenue-weighted average Altman Z-score of major tenants. Leverage is the ratio of total debt to total market assets, where we define market assets as the total book assets plus the difference between the market value of equity and the book value of equity. Funds from operations (FFO) growth is the annual percentage change in such funds. Dilution is the total amount of offering divided by the market cap prior to the new issue. We measure profitability by the return on average assets (ROAA). Market-to-book is the total book assets divided by the total market value of assets. Z-statistics are shown in the line below the coefficient. ${ }^{*}, * *$, and ${ }^{* * *}$ indicate statistical significance at the $10 \%, 5 \%$, and $1 \%$ levels, respectively.

\begin{tabular}{|c|c|c|c|c|c|c|}
\hline \multirow{3}{*}{$\begin{array}{r}\text { Measures of } \\
\text { Liquidation Value }\end{array}$} & \multicolumn{2}{|c|}{ Model 1} & \multicolumn{2}{|c|}{ Model 2} & \multicolumn{2}{|c|}{ "Model 3} \\
\hline & Coefficient & $\begin{array}{l}\text { Change } \\
\text { in Prob. }\end{array}$ & Coefficient & $\begin{array}{l}\text { Change } \\
\text { in Prob. }\end{array}$ & Coefficient & $\begin{array}{l}\text { Change } \\
\text { in Prob. }\end{array}$ \\
\hline & & & & & & \\
\hline MSA Industry & $-0.362^{* * *}$ & $-6.3 \%$ & $-0.354^{* * *}$ & $-6.2 \%$ & -0.204 & $-3.6 \%$ \\
\hline Concentration & -2.927 & & -2.858 & & -1.519 & \\
\hline Tenant Quality & $\begin{array}{l}0.105^{* * *} \\
3.088\end{array}$ & $5.8 \%$ & $\begin{array}{l}0.105^{* * *} \\
3.081\end{array}$ & $5.8 \%$ & $\begin{array}{l}0.124^{* * *} \\
3.494\end{array}$ & $6.9 \%$ \\
\hline Control Variables & & & & & & \\
\hline Lease Maturity & & & $\begin{array}{l}-0.010 \\
-0.101\end{array}$ & $-0.2 \%$ & $\begin{array}{l}-0.061 \\
-0.593\end{array}$ & $-1.1 \%$ \\
\hline Leverage & & & & & $\begin{array}{l}-6.050^{* * *} \\
-6.127\end{array}$ & $-16.5 \%$ \\
\hline Profitability & & & & & $\begin{array}{l}-0.032 \\
-1.439\end{array}$ & $-3.6 \%$ \\
\hline Market-to-book & & & & & $\begin{array}{c}-0.763^{*} \\
-1.673\end{array}$ & $-4.2 \%$ \\
\hline Dilution & & & & & $\begin{array}{l}0.949 \\
1.372\end{array}$ & $3.2 \%$ \\
\hline FFO Growth & & & & & $\begin{array}{l}-0.009^{* * *} \\
-2.933\end{array}$ & $-6.7 \%$ \\
\hline Size & $\begin{array}{l}0.877^{* * *} \\
10.00\end{array}$ & $24.7 \%$ & $\begin{array}{l}0.896^{* * *} \\
10.690\end{array}$ & $24.7 \%$ & $\begin{array}{l}1.022^{* * *} \\
10.140\end{array}$ & $28.4 \%$ \\
\hline Intercept & $\begin{array}{l}-10.500^{* * *} \\
-5.406\end{array}$ & & $\begin{array}{l}-10.580 \text { *** } \\
-5.712\end{array}$ & & $\begin{array}{c}-9.988^{* * *} \\
-4.705\end{array}$ & \\
\hline Pseudo $R^{2}$ & 0.1 & & 0.1 & & & \\
\hline Log Likelihood & -49 & & -49 & & -46 & \\
\hline Observations & 86 & & 86 & & 86 & \\
\hline
\end{tabular}




\section{Table 11: Robustness Check - Regression Results with Market Measures of REIT Liquidation Value (Sample Selection Criteria 3)}

This table presents the multivariate logit regression results of REITs' incremental financing decisions for a sample selected under sample selection criterion 3. We include observations if any one of the two market measures for liquidation value are available. Criteria 3 generates $1,448(1,300)$ observations for the capitalization rate (loss severity rate) sample. The dependent variable is set to one for a new bond issue, and zero for an equity issue. We measure liquidation value separately by the self-constructed firm level capitalization rate and firm level realized loss severity rate. Leverage is the ratio of total debt to total market assets, where we define market assets as the total book assets plus the difference between the market value of equity and the book value of equity. Funds from operations (FFO) growth is the annual percentage change in such funds. Dilution is the total amount of offering divided by the market cap prior to the new issue. We measure profitability by the return on average assets (ROAA). Market-to-book is the total book assets divided by the total market value of assets. Z-statistics are shown in the line below the coefficient. *, **, and *** indicate statistical significance at the $10 \%, 5 \%$, and $1 \%$ levels, respectively.

\begin{tabular}{|c|c|c|c|c|c|c|}
\hline \multirow[b]{2}{*}{ Variables } & \multicolumn{3}{|c|}{ Model 4} & \multicolumn{3}{|c|}{ Model 5} \\
\hline & \multicolumn{2}{|l|}{ Coefficient } & \multirow[t]{2}{*}{$\begin{array}{l}\text { Change } \\
\text { in Prob. }\end{array}$} & \multicolumn{2}{|l|}{ Coefficient } & $\begin{array}{l}\text { Change } \\
\text { in Prob. }\end{array}$ \\
\hline \multirow{2}{*}{\multicolumn{7}{|c|}{$\begin{array}{r}\text { Measure of } \\
\text { Liquidation Value }\end{array}$}} \\
\hline & & & & & & \\
\hline Cap Rate & $\begin{array}{l}-0.262 \\
-2.816\end{array}$ & $* * *$ & $-4.3 \%$ & & & \\
\hline Loss Severity & & & & $\begin{array}{c}-0.024 \\
3.884\end{array}$ & $* * *$ & $-5.4 \%$ \\
\hline \multicolumn{7}{|l|}{ Control Variables } \\
\hline Leverage & $\begin{array}{l}-2.154 \\
-3.796\end{array}$ & $* * *$ & $-6.7 \%$ & $\begin{array}{l}-3.518 \\
-5.371\end{array}$ & $* * *$ & $-10.8 \%$ \\
\hline Profitability & $\begin{array}{l}-0.011 \\
-0.663\end{array}$ & & $-1.2 \%$ & $\begin{array}{l}-0.029 \\
-1.400\end{array}$ & & $-3.0 \%$ \\
\hline \multirow[t]{2}{*}{ Market-to-book } & 0.115 & & $0.7 \%$ & 0.004 & & $0.0 \%$ \\
\hline & 0.362 & & & 0.011 & & \\
\hline \multirow[t]{2}{*}{ Dilution } & 1.163 & $* *$ & $4.7 \%$ & 1.291 & $* * *$ & $5.2 \%$ \\
\hline & 2.536 & & & 2.713 & & \\
\hline \multirow[t]{2}{*}{ FFO Growth } & -0.006 & $* * *$ & $-4.9 \%$ & -0.009 & $* * *$ & $-7.3 \%$ \\
\hline & -3.067 & & & -3.947 & & \\
\hline \multirow[t]{2}{*}{ Size } & 0.861 & $* * *$ & $23.9 \%$ & 1.024 & $* * *$ & $27.7 \%$ \\
\hline & 12.840 & & & 13.450 & & \\
\hline \multirow[t]{2}{*}{ Intercept } & -9.682 & $* * *$ & & -13.010 & $* * *$ & \\
\hline & -6.006 & & & -10.500 & & \\
\hline Pseudo $R^{2}$ & & 0.137 & & & 0.176 & \\
\hline Log Likelihood & & 856.0 & & & 737.0 & \\
\hline Observations & & 1448 & & & 1300 & \\
\hline
\end{tabular}




\section{Table 12: Robustness Check - Financing Choice by Firms That Have No Tenants}

This table presents the multivariate logit regression results of REITs' incremental financing decisions for REITs that do not have tenants. Without tenant information, only market measures of liquidation value are available to test Shleifer and Vishny's (1992) theory. The dependent variable is set to one for a new bond issue, and zero for an equity issue. We measure liquidation value separately by the self-constructed firm level capitalization rate and firm level realized loss severity rate. Leverage is the ratio of total debt to total market assets, where we define market assets as the total book assets plus the difference between the market value of equity and the book value of equity. Funds from operations (FFO) growth is the annual percentage change in such funds. Dilution is the total amount of offering divided by the market cap prior to the new issue. We measure profitability by the return on average assets (ROAA). Market-to-book is the total book assets divided by the total market value of assets. Z-statistics are shown in the line below the coefficient. *, **, and *** indicate statistical significance at the $10 \%, 5 \%$, and $1 \%$ levels, respectively.

\begin{tabular}{|c|c|c|c|c|c|c|}
\hline \multirow{2}{*}{ Variables } & \multicolumn{3}{|c|}{ Model 4} & \multicolumn{3}{|c|}{ Model 5} \\
\hline & \multicolumn{2}{|l|}{ Coefficient } & \multirow[t]{2}{*}{$\begin{array}{l}\text { Change } \\
\text { in Prob. }\end{array}$} & \multicolumn{2}{|l|}{ Coefficient } & \multirow[t]{2}{*}{$\begin{array}{l}\text { Change } \\
\text { in Prob. }\end{array}$} \\
\hline $\begin{array}{l}\text { Measure of } \\
\text { Liquidation Value }\end{array}$ & & & & & & \\
\hline Cap Rate & $\begin{array}{l}-0.454 \\
-2.933\end{array}$ & $* * *$ & $-8.7 \%$ & & & \\
\hline Loss Severity & & & & $\begin{array}{l}-0.052 \\
-5.119\end{array}$ & $* * *$ & $-15.9 \%$ \\
\hline Control Variables & & & & & & \\
\hline Leverage & $\begin{array}{l}0.551 \\
0.641\end{array}$ & $* * *$ & $2.4 \%$ & $\begin{array}{l}-1.454 \\
-1.410\end{array}$ & $* * *$ & $-5.3 \%$ \\
\hline Profitability & $\begin{array}{l}0.008 \\
0.205\end{array}$ & & $0.6 \%$ & $\begin{array}{l}-0.012 \\
-0.276\end{array}$ & & $-1.0 \%$ \\
\hline Market-to-book & $\begin{array}{l}0.841 \\
1.591\end{array}$ & & $5.4 \%$ & $\begin{array}{l}0.517 \\
0.902\end{array}$ & & $3.3 \%$ \\
\hline Dilution & $\begin{array}{l}2.075 \\
2.285\end{array}$ & $* *$ & $9.4 \%$ & $\begin{array}{l}2.407 \\
3.050\end{array}$ & $* * *$ & $11.5 \%$ \\
\hline FFO Growth & $\begin{array}{l}-0.004 \\
-1.178\end{array}$ & *** & $-3.9 \%$ & $\begin{array}{l}-0.004 \\
-1.220\end{array}$ & $* * *$ & $-4.9 \%$ \\
\hline Size & $\begin{array}{l}0.723 \\
5.240\end{array}$ & *** & $17.0 \%$ & $\begin{array}{l}1.267 \\
6.770\end{array}$ & $* * *$ & $28.6 \%$ \\
\hline Intercept & $\begin{array}{l}-8.048 \\
-2.773\end{array}$ & $* * *$ & & $\begin{array}{c}-17.440 \\
-6.176\end{array}$ & $* * *$ & \\
\hline $\begin{array}{l}\text { Pseudo } R^{2} \\
\text { Log Likelihood } \\
\text { Observations }\end{array}$ & & $\begin{array}{c}0.102 \\
-247.9 \\
408\end{array}$ & & & $\begin{array}{l}0.208 \\
197.3 \\
363\end{array}$ & \\
\hline
\end{tabular}

